\title{
LACTOFERRIN AND CANCER DISEASE PREVENTION
}

\author{
Lígia Rodrigues, ${ }^{1 *}$ José Teixeira, ${ }^{1}$ Fernando Schmitt, ${ }^{2,3}$ Marie Paulsson, ${ }^{4}$ Helena \\ Lindmark Månsson, ${ }^{4,5}$
}

${ }^{1}$ IBB - Institute for Biotechnology and Bioengineering, Centre of Biological Engineering, Campus de Gualtar, 4710-057 Braga, Portugal,

${ }^{2}$ Instituto de Patologia e Imunologia Molecular - IPATIMUP, Universidade do Porto, Rua Dr. Roberto Frias, 4200-465 Porto, Portugal,

${ }^{3}$ Faculdade de Medicina, Universidade do Porto, Al. Prof. Hernâni Monteiro 4200 - 319 Porto, Portugal,

${ }^{4}$ Department of Food Technology, Engineering and Nutrition, Lund University, P.O. Box 124, S-221 00, Lund, Sweden,

${ }^{5}$ Swedish Dairy Association, Scheelevägen 18, SE-223 63 Lund, Sweden.

Running title: Cancer disease prevention

Keywords: lactoferrin, chemoprevention, infection, inflammation, cancer

Corresponding author:

* Lígia Rodrigues

IBB - Institute for Biotechnology and Bioengineering

Centre of Biological Engineering

Campus de Gualtar, 4710-057 Braga, Portugal.

Tel. 351-253-604400

Fax 351-253-678986

e-mail: lrmr@deb.uminho.pt 


\section{ABSTRACT}

Lactoferrin (LF) is an iron-binding glycoprotein that composes the transferrin family and is predominantly found in the products of the exocrine glands located in the gateways of the digestive, respiratory and reproductive systems, suggesting a role in the non-specific defence against invading pathogens. Additionally, several physiological roles have been attributed to LF, namely regulation of iron homeostasis, host defence against infection and inflammation, regulation of cellular growth and differentiation and protection against cancer development and metastasis. These findings have suggested LF's great potential therapeutic use in cancer disease prevention and/or treatment, namely as a chemopreventive agent. This review looks at the recent advances in understanding the mechanisms underlying the multifunctional roles of LF and future perspectives on its potential therapeutic applications. 


\section{INTRODUCTION}

Over the past few decades, clinical and mechanistic studies have indicated many relations between nutrition and health, thus evidence that diet is a key environmental factor affecting the incidence of many chronic diseases is overwhelming. The precise extent of this contribution is difficult to judge, but a reduction of $35 \%$ in the age standardized incidence of cancer in the United States has been proposed to be achievable via "practicable dietary means" (Elliot and Ong, 2002; Davis and Milner, 2004; Petricoin and Liotta, 2003). Indeed, several food derived compounds we eat are among the most promising chemopreventive agents being evaluated. Chemoprevention is defined as using chemicals with the goal of preventing, interrupting or reversing the carcinogenic process. Since carcinogenesis is a multistage process, which usually takes many years in humans, there is ample opportunity to intervene and prevent the development of cancer. Chemopreventive agents are ultimately expected to be in widespread use by the general population. Therefore, they need to be non-toxic, inexpensive and available for use by oral via. With the demonstration of Tamoxifen ability to prevent breast cancer in women, the feasibility of chemoprevention in humans has now been well established (Jordan and Morrow, 1999) The full extent of biologically active components in our diet is unknown, and our understanding of their mechanisms of action is even more limited (Petricoin and Liotta, 2003). Much of the available data has been derived from in vitro studies with purified compounds in forms and concentrations to which the tissues in our bodies may never be exposed (Davis and Milner, 2004; Petricoin and Liotta, 2003). Furthermore, nutrition research has traditionally concentrated on single issues (such as reducing risk of cardiovascular disease or cancer) in "at risk" individuals, whereas what we need to address is the question of all the possible effects of specific food components in a genetically heterogeneous population. This is especially important for determining unintended risk as well as unintended benefit (Elliot and Ong, 2002; Davis and Milner, 2004). 
A promising field of research is clinical studies with cancer preventive proteins existing in milk (McIntosh, 1993; Tsuda et al., 2002), namely lactoferrin (LF). LF known for its inhibitory action on cell proliferation, as well as for its anti-inflammatory and antioxidant abilities, has been described to have anti-carcinogenic properties in several in vivo and in vitro studies (Baveye et al., 1999; Brock, 2002; Nuijens et al., 1996; Tsuda et al., 2000, 2002; Ward et al., 2002; Ushida et al., 1999; Sekine et al., 1997a; Iigo et al., 1999; Wang et al., 2000; Matsuda et al., 2006; Pan et al., 2007). Nevertheless, it is still poorly understood if orally administrated LF is absorbed from the intestine, and if it exerts its protective effect at the site were it is expected, especially in the case of diseases occurring at sites distant from the gastrointestinal tract.

Many food components in the form of biologically active proteins, peptides, lipids, and other substances survive the digestive processes and can enter the circulation. Thus, it is possible that absorbed intact peptides can exert biological activities during health and disease. Lactoferricin (LFCin) is a peptide fragment produced by acid-pepsin hydrolysis of LF. Although LFCin has attracted considerable interest because of its well established antimicrobial activity (Yamauchi et al., 1993), recent evidence indicates that orally or subcutaneously administrated LFCin also possesses potent in vivo activity against cancer cells, namely inhibiting metastasis, angiogenesis and tumour growth (Cho et al., 2004; Yoo et al., 1997a). However, the mechanisms by which LFCin exerts its action are still unknown.

Regardless of LF reported potential, very few studies have covered an integrated and systematic approach to its effects as an anti-cancer agent on breast cancer (Benaissa et al., 2005; Teng et al., 2004; Miyamoto et al., 2005; Giancotti, 2006), although some high-throughput techniques, such as DNA microarrays and proteomics, have already been applied (Forozan et al., 2000; Perou et al., 1999; Shan et al., 2002) without a consistent application of bioinformatics tools for data interpretation. Therefore, it remains a large task to identify the mechanisms by which LF and its digested fragments exert their action and to discover innovative means to supply them to consumers. 
This review aims to provide an overview of LF functions and mechanisms of interaction that could be exploited further in developing its potential therapeutic applications, namely in cancer disease prevention and/or treatment.

\section{LACTOFERRIN OCCURRENCE AND STRUCTURE}

LF was firstly recognised as a single-chain iron-binding protein (Groves, 1960; Johanson, 1960; Montreuil et al., 1960) and the names given to it, LF or lactotransferrin, firmly assigned it to the family of proteins known as the transferrins. The archetypal members of the transferrin family are LF, serum transferrin and ovotransferrin, with ovotransferrin being equivalent to avian serum transferrin, differing only in its glycosylation (Baker, 1994). These proteins are all glycoproteins that typically exhibit 50-70\% pair wise sequence identity (Metz-Boutigue et al., 1984; Pierce et al., 1991; Moore et al., 1997). Between LF and serum transferrins the sequence identity is around 60\% and between LF from different species it is around 70\% (Baker, 1994; Baker and Baker, 2005; Teng et al., 2002; Bowman et al., 1988), for example bovine LF (bLF) shares 69\% amino acid identity with human LF (hLF) (Shah, 2000; Pierce et al., 1991). LF is predominantly found in the products of the exocrine glands located in the gateways of the digestive, respiratory and reproductive systems. Thus, LF can be found in the secreted milk, in tears, synovial fluids, saliva and seminal fluid (Lönnerdal, 2003). Table 1 shows a selection of the LF amounts reported from these various biological fluids. Additionally, LF can be found in blood and plasma LF is derived from neutrophils, which degranulate and synthesize the protein during inflammation (Britigan et al., 1994; Levay and Viljoen, 1995; Iyer and Lönnerdal, 1993; Van Snick et al., 1974). Some physico-chemical properties of LF are summarized in Table 2.

Structurally, LF is folded into two lobes, representing its N- and C-terminal halves (Baker et al., 1994), that show sequence homology with each other and can each reversibly bind one ferric ion along with a synergistic anion, usually bicarbonate (Baker, 1994; Steijns and Hooijdonk, 2000). In these respects it closely resembles transferrin, although its affinity for iron is somewhat higher, allowing iron to be retained at lower $\mathrm{pH}$ values (Mazurier and Spik, 1980; Peterson et 
al., 2000). This gives LF a more potent iron withholding ability (Baker et al., 2002). The lobes are connected by a peptide of 10-15 residues, which in LF forms a 3-turn $\alpha$-helix, but in transferrins is irregular and flexible. There are non-covalent interactions, mostly hydrophobic where the two lobes pack together (Haridas et al., 1995).

\section{LACTOFERRIN GENE EXPRESSION AND REGULATION}

In situ fluorescence hybridization indicated that the hLF gene is mapped in the region 3p21.3 (Kim et al., 1998; Klintworth et al., 1997; Teng et al., 1987), organized in 17 exons and its total length is about $24.5 \mathrm{~kb}$. A comparison of the structure of the hLF gene with that of other species revealed that it is more closely related to bLF than to murine LF (Furmanski et al., 1989; Geng et al., 1998). The positions of the introns are well matched with those of the bLF gene except only for exons 14 and 15. All the exon-intron boundaries of the gene conform to the GT/AG rule. Although LF is highly conserved among several species, its expression is both ubiquitous and species, tissue, and cell-type specific (Das et al., 1999; Furmanski et al., 1989; Grant et al., 1999; Shigeta et al., 1996; Teng et al., 2002). It is differentially regulated through multiple signalling pathways such as steroid hormone, growth factor, and kinase cascade pathways (Das et al., 1997; Teng et al., 2002; Close et al., 1997).

Expression of the LF gene is both constitutive and inducible. During the differentiation of myeloid cells, the LF gene responds to the developmental signals and is transcribed in the myelocyte and metamyelocyte stages (Berliner et al., 1995; Khanna-Gupta et al., 2000). While LF is constitutively expressed in the wet surface mucosa, LF is estrogen inducible in uterine tissue (Pentecost and Teng, 1987; Teng et al., 1986, 1989). Moreover, the presence of LF in the human reproductive tract has also been localized in the prostate and seminal vesicle of males (Goodman and Young, 1981; Wichmann et al., 1989) and is a major coat protein of human sperm (Hekman and Rumke, 1969).

Since the LF gene promoter consists of multiple response elements for various signalling pathways such as the route for kinase cascade, the estrogenic compounds could act through 
response elements other than ERE (estrogen response element) to activate the gene (Teng, 2006; Giancotti, 2006) .

There are few studies on the regulation of LF gene expression other than that by hormones. In a cultured mouse mammary epithelial cell system, LF expression was induced at high cell density in the absence of exogenously added basement membranes or prolactin (Close et al., 1997), although an earlier study suggested that LF expression in a mouse mammary gland explants is stimulated by prolactin (Green and Pastewka, 1978). Close and co-workers (1997) demonstrated that LF expression in mammary epithelial cells is mediated by changes in cell shape and actin cytoskeleton. This observation offers an explanation for the suppression of LF expression in monolayer culture and in malignant tissues in which inappropriate cell shapes and cytoskeletal structures are manifested under these conditions. Multiple signalling pathways and diverse regulatory proteins regulate LF gene expression in either a positive or negative manner (Teng, 2006). Although the mechanism of regulation is still unknown, the factors involved in LF gene expression could provide clues as to where LF is needed and under what conditions.

\section{LACTOFERRIN METABOLISM AND RECEPTORS}

LF is produced in neutrophils and stored in specific granules and possibly in tertiary granules (Iyer and Lönnerdal, 1993; Lönnerdal, 2003; Van Snick et al., 1974). The steroid-thyroid receptor super family works in concert to modulate LF gene expression supporting the hypothesis that LF levels are hormone dependent (Levay and Viljoen, 1995; Giancotti 2006; Teng, 2006). LF, unlike myeloperoxidase and some other granular products, is not synthesized as a larger precursor and was found to be unphosphorylated (Olsson et al., 1988). The neutrophil LF within the granules can either be secreted into the surrounding tissues or blood (Van Snick et al., 1974), or the granules can fuse with phagosomes (Maher et al., 1993). Secretion from polymorphonuclear cells into the circulation is dependent on degranulation factors, which in turn appear to be dependent on the activation of guanylate cyclase, cGMP and proteinkinase $\mathrm{C}$ (calcium dependent). This occurs in both aerobic and anaerobic conditions, is 
unaffected by the presence of hydrogen sulphide and is stimulated by IL-8 and surface bound IgG (Maher et al., 1993; Kahler et al., 1988). Plasma LF levels generally increase in iron overload, inflammation, infectious diseases, and during tumour development, demonstrating a multifactor stimulatory mechanism for LF release from neutrophils (Levay and Viljoen, 1995, Bullen et al., 2006).

LF removal from circulation appears to occur in one of two ways. First, LF can be removed from the circulation, as well as from the interstitial spaces, by what would appear to be receptormediated endocytosis into phagocytic cells such as macrophages, monocytes and other cells of the RES (reticuloendothelial system), with subsequent transfer of the iron to ferritin (Olofsson et al., 1977; Van Snick et al., 1974, 1976). However, some controversy with regard to the cells involved in this way of LF removal still exists (Ismail and Brock, 1993). The alternative mode of LF removal would be its direct uptake by the liver by liver endothelial cells and hepatocytes (Hu et al., 1993). Bennet and Kokocinski (1979) showed that labelled LF was rapidly cleared from the circulation by the liver and spleen. Nevertheless, it is still not established whether LF, like transferrin, is recycled (Birgens et al., 1988). Further research is needed to fully understand LF metabolism in the human adult. The kidneys appear to play a role in LF clearance from the circulation since both LF and LF fragments were found in the urine of infants (Hutchens et al., 1991). Both faecal and urinary elimination of LF, however, need further investigation because significant controversy still exists (Desai et al., 2007; Hirata et al., 2007; Yamauchi et al., 2006).

LF receptors have been identified in the gastrointestinal tract, on leukocytes and macrophages, platelets, and on bacteria. The surface of the LF molecule has several regions with high concentrations of positive charge responsible for one of the features that distinguishes LF from other transferrins and for some unique properties (Lampreave et al., 1990; Zakharova et al., 2000; Baker, 1994; Van Berkel et al., 1997). The most striking region of positive charge comprises the N-terminus of the polypeptide chain (with the sequence GRRRRS in hLF) which projects from the protein surface and the adjacent C-terminus of helix 1 where residues 27-30 have the sequence RKVR (Baker et al., 2002; Rochard et al., 1989). This region provides a site 
for binding heparin (Van Berkel et al., 1997) and glycosaminoglycans (Mann et al., 1994) and is very likely the site that binds DNA. It may also be important for the ability of LF to bind to many cell types, possibly through binding to the negatively charged phospholipids groups of the cell membranes (Yu and Schryvers, 1993). The similarity of the N-terminal sequence (GRRRRS) to a common nuclear localisation signal sequence motif in eukaryotes could further explain the observation that LF can enter the nucleus (He and Furnmanski, 1995). Contiguous with the $\mathrm{N}$-terminal patch is helix 1 , which forms the main part of the bactericidal "lactoferricin" domain (Bellamy et al., 1992), which is characterised by its display of surface arginine residues. Despite their virtually identical fold, other transferrins do not share this bactericidal activity, presumably because they lack the necessary surface features. The other main concentration of positive charge is in the inter-lobe region, associated with the helix that joins the two lobes. This also appeals as a likely DNA binding region, both because of the charge and because of the cleft that is formed between the lobes, which could create a docking site.

\section{LACTOFERRIN FUNCTIONS}

Because of its close resemblance to transferrin, initial research on LF function was directed towards establishing functions related to its iron-binding properties, namely iron absorption, antimicrobial activity, and modulation of iron metabolism during inflammation. However, despite their structural similarities, LF differs from its serum counterpart in several important aspects including location and functional activity. LF has been proposed to play a role in intestinal iron absorption, regulation of cellular proliferation and differentiation, protection against microbial infection, anti-inflammatory responses, regulation of myelopoiesis, immunomodulation and cancer prevention (Pan et al., 2007; Ward et al., 2005; Naidu, 2002; Min and Krochta, 2005; Steijns and Van Hooijdonk, 2000; Baveye et al., 1999; Nuijens et al., 1996; Levay and Viljoen, 1995; Iyer and Lönnerdal, 1993; Sanchez et al., 1992). Table 3 summarizes some of the established physiological roles for LF and its mechanisms. 
The reported antimicrobial activities (Santagati et al., 2005; Valenti et al., 1998; Levay and Viljoen, 1995) of LF highlight the many possible modes by which it can contribute to host protection against microbial infections at the mucosal surfaces, namely by growth inhibition as a result of iron scavenging (Nemet and Simonovits, 1985; Brock, 1980), disruption of the bacterial cell membranes (Yamauchi et al., 1993; Ellison and Giehl, 1991; Al-Nabulsi and Holley, 2006) or blocking of cell-virus interactions (Andersen et al., 2001; Ikeda et al., 2000; Siciliano et al., 1999; Giansanti et al., 2002).

Regarding LF anti-inflammatory activity several mechanisms of action by blocking or inhibiting key mediators of the inflammatory response have also been proposed, such as binding to LPS (Miyazawa et al., 1991); inhibition of several cytokines (TNF- $\alpha$ and IL-1 $\beta$ ) (Machnicki et al., 1993; Crouch et al., 1992; Slater and Fletcher, 1987; Baveye et al., 1999) or binding to bacterial CpG motifs (Britigan et al., 2001). Moreover, LF was found to elevate the number and increase the activity of T and B lymphocytes and NK cells (Dhennin-Duthille et al., 2000; Goretzki and Mueller, 1998), stimulate the release of a number of cytokines (Hangoc et al., 1991), increase phagocytic activity and cytotoxicity of monocytes/macrophages (Birgens et al., 1984; Van Snick and Masson, 1976), accelerate the maturation of T and B cells, and elevate the expression of several types of cellular receptors (Adamik et al., 1998; Bennett and Davis, 1981; Frydecka et al., 2002; Zimecki et al., 1991, 1995). Many immunological mechanisms are critically dependent upon cell-cell interactions; the number and affinity of interactions between two cells can often affect the nature of downstream events. The ability of LF to bind to cell surfaces is likely to affect these parameters, and could thus give rise to altered immune responses (Legrand et al., 2005).

\section{Lactoferrin and iron metabolism}

Despite much research into the interactions of LF with cells and tissues, there is still no good evidence that it plays any role as an iron-transport molecule or indeed is involved in “mainstream” iron metabolism (Brock, 2002). Nevertheless, it is consensual that LF influences the iron availability (Levay and Viljoen, 1995). 
Iron is an element necessary for many metabolic functions of cells including cell proliferation. Therefore, cells and organisms have developed elaborate mechanisms of uptake and storage of iron to facilitate the utilization of this element in metabolic processes and in cell proliferation and at the same time to keep concentrations of free iron at a minimum. In normal physiological processes, iron uptake, storage and utilization are carefully regulated. Cellular damage arising from free radicals, generated by available iron, is kept at a low level by cellular defences and DNA repair systems (Liehr and Jones, 2001).

While iron supplementation and iron enrichment of foods is widely accepted, there have been persistent concerns about potential deleterious effects, because iron enhances colon and mammary carcinogenesis in rodents and because elevated body iron stores increase the risk of several cancers in humans (Weinberg, 1984, 1992; Selby and Friedman, 1988; Stevens et al., 1988). There is also indirect, but substantial evidence supporting a role of iron metabolism in breast cancer. For instance, a six-fold higher tissue ferritin concentration has been measured in malignant carcinoma of the breast compared to normal or benign tissue (Weinstein et al., 1982; Elliott et al., 1993). Furthermore, transferrin and tumour cell transferrin receptor proteins were elevated in breast carcinoma compared to normal or benign cells (Faulk et al., 1980; Rossiello et al., 1984).

All these data taken together indicate that iron enhances tumour development in humans.

Certainly, proliferating tumour cells require iron and therefore tumour tissue may have increased transferrin receptor and ferritin levels.

Current evidence suggests that while LF plays no major role in normal iron homeostasis (Ward et al., 2005), it may contribute to alterations in iron metabolism during infection or inflammation. In addition, the iron-binding function of LF may contribute to other physiological functions.

\section{Lactoferrin and human cancer}

Many functions have been described for LF over the years, but concerning its anti-tumour role and mechanisms involved there is still a big controversy on whether LF's iron-binding activity 
is implicated or not. Lonnerdal and Iyer (1995) state that it is likely to be the iron-binding properties of LF that contribute to its anti-tumour properties, since free iron may act as a mutagenic promoter by inducing oxidative damage to nucleic acid structure (Weinberg, 1984, 1992,1996). It is thought that LF may bind iron locally in tissues, therefore reducing the risk of oxidant-induced tumourigenesis (Stevens et al., 1988). Moreover, estrogenic hormones appear to regulate the uptake of iron and its utilization in proliferative processes (Liehr and Jones, 2001; Teng, 2006). Nevertheless, much research needs to be carried out in future to outline in more detail the regulation of iron metabolism by estrogen. Tumours may thus arise in cells, which are damaged by such processes and which at the same time are stimulated to proliferate by hormone receptor-mediated mechanisms. The possible contribution of iron to genetic lesions and to cell proliferation indicates that this element plays a crucial role in the development of estrogen-dependent neoplasms such as breast or uterine cancers (Weinstein et al., 1982; Elliot et al., 1993; Faulk et al., 1980; Rossiello et al., 1984). Therefore, such hormone responsive tumour development may be prevented by iron chelators (Ghio et al., 1992; Lund and Aust, 1990; Giancotti, 2006). Another possibility is the restriction of dietary iron intake and dietary iron supplements, or the diet supplementation with LF, as part of a strategy to reduce tumour development. Such studies need to be carried out in the future.

On the other hand, several other mechanisms have been described for the LF anti-tumour role, such as regulation of NK cell activity (Damiens et al., 1998; Matsuda et al., 2006), modulation of expression of G1 proteins (Damiens et al., 1999; Xiao et al., 2004), inhibition of VEGF(165)mediated angiogenesis (Norrby et al., 2001), and enhancement of apoptosis (Yoo et al., 1997b; Sakai et al., 2006).

Damiens and co-workers (1998) investigated LF involvement, at inflammatory concentrations, in cancer progression. It was reported that LF has a significant effect on NK cell cytotoxicity against haematopoietic and breast epithelial cell lines. By pre-treatment of either NK cells or target cells with LF, it was demonstrated that the LF effect is due both to a modulation of NK cell cytotoxicity and the target cell sensitivity to lysis. It was also shown that LF inhibits epithelial cell proliferation by blocking the cell cycle progression. Furthermore, Damiens and 
co-workers (1999) found that treatment of breast carcinoma cells MDA-MB-231 with hLF induced growth arrest at the G1 to S transition of the cell cycle by modulating the expression and the activity of key regulatory proteins.

The effect of orally administered iron-unsaturated bLF on angiogenesis induced by VEGF165 and IL-1- $\alpha$ in adult rats was assessed by Norrby and co-workers (2001). LF treatment was found to significantly inhibit the VEGF165-mediated response in terms of microvessel spatial extension, overall vascularity and incidence of crossover. Thus, the oral administration of LF thus appears to be of potential interest as an anti-angiogenesis treatment modality in the clinical setting.

Additionally, the activity of bovine LFCin to induce apoptosis in THP-1 human monocytic leukemic cells was considered (Yoo et al., 1997b). The results achieved suggested that LFCin, but not LF itself, is able to induce apoptosis in THP-1 human monocytic tumour cells, and that its apoptosis-inducing activity is related to the pathway mediated by production of the intracellular reactive oxygen species (ROS) and activation of $\mathrm{Ca}^{2+} / \mathrm{Mg}^{2+}$-dependent endonucleases.

Finally, there have also been a number of animal studies showing that LF can inhibit development of experimental tumours (Ushida et al., 1998; Tsuda et al., 2002).

Although the results achieved by several researchers point to a clear anti-tumour role of LF (Benaissa et al., 2005), the mechanisms by which it is exerted are not fully understood, thus further work on this subject is warranted.

\section{LACTOFERRIN AS A CHEMOPREVENTIVE AGENT}

Several studies have been done to evaluate the effect of orally administrated LF in healthy or diseased human beings and animals (Tomita et al., 2002; Teraguchi et al., 2004). To the date, it has become evident that the oral administration of LF exerts various beneficial effects against diseases (Table 4), namely as a chemopreventive agent. For the practical use of chemopreventive agents, it is important to know whether their action is limited to only 
inhibition. Therefore, use of chemopreventive agents should follow appropriate indications based on reliable information regarding beneficial preventive and adverse promoting or toxic effects (Tsuda et al., 2000). A thorough follow-up of patients or populations during and after the administration of chemopreventive agents is obviously necessary for effective assessment and conclusions to be drawn. For general public use, the agents require safety approval based on a long-term toxicity or carcinogenicity testing. Further development of appropriate in vivo animal assay systems to provide reliable information regarding organotropism and adverse effects is also critical for this purpose. To this regard, use of naturally occurring compounds is advantageous because most of them are ingested routinely as food components. Fiber, unsaturated fatty acid, carotenoids, flavonoids, phenolic compounds, especially polyphenols, and now bLF could be promising compounds in this respect. bLF as a food ingredient is thought to be safe, because there is a long dietary history of its use. People who live on dairy products must have ingested bLF for a long time, as raw milk and natural cheese contain high amounts of this protein. A human clinical study in chronic hepatitis C patients showed that high bLF oral doses, up to $7.2 \mathrm{~g} /$ body/day were well tolerated (Okada et al., 2002).

Troost and co-workers (2001) demonstrated that over than $60 \%$ of administrated bLF survives the passage through adult human stomach and enters the small intestine in an intact form. On the other hand, analysis of the gastric contents revealed that LFCin B was formed at a molar concentration corresponding to $4.5 \%$ of ingested bLF (Kuwata et al., 1998a). When the animals were given free access to milk containing bLF at $40 \mathrm{mg} / \mathrm{ml}(482 \mu \mathrm{mol} / \mathrm{l})$, the levels of bLF fragments containing the LFCin B region in the contents of the stomach, upper small intestine, and lower small intestine were approximately 200, 20 and $1 \mu \mathrm{mol} /$, respectively (Kuwata et al., 1998b; Kuwata et al., 2001). Some parts of ingested LF are likely to be not fully digested and to be present in the lower gastrointestinal tract. These intact bLF and partially digested bLF peptides, which retain biological activities, may exert various physiological effects in the digestive tract.

Orally administrated LF exhibits several beneficial effects at sites other than the digestive tract. In the case of infants or adults with injury in the intestine, it is possible that ingested LF enters 
the blood circulation and acts systemically. However, neither bLF nor functional bLF fragments (LFCin B-containing peptides and anti-bLF antibody-binding peptides) were at a level higher than the detection limit $(1 \mathrm{mg} / \mathrm{ml})$ detected in the portal blood of normal adult rats orally given bLF at a maximal dose of $5 \mathrm{~g} / \mathrm{kg}$ (Wakabayashi et al., 2004). Therefore, LF-related molecules are not likely to be transported from the intestine into the circulation. Hence, it is rational to consider that oral administered bLF and its digested products act initially on the intestinal immune system and augment the protective immunity systemically (Teraguchi et al., 2004).

The protective effect of LF against chemically induced carcinogenesis, tumour growth and/or metastasis have been demonstrated in an increasing number of animal model experiments, namely directed to specific organs, such as esophagus, tongue, lung, liver, colon and bladder (Bezault et al., 1994; Wang et al., 2000; Shimamura et al., 2004; Yoo et al., 1997a; Iigo et al., 1999; Tsuda et al., 2002; Ushida et al., 1999; Tanaka et al., 2000; Fujita et al., 2002; Masuda et al., 2000; Sekine et al., 1997a; Varadhachary et al., 2004; Kuhara et al., 2000). Table 5 summarizes the effectiveness of orally administrated LF-related compounds on cancer. Despite the evidence that LF possesses chemopreventive activity, little is known about (i) its anti-cancer activity against established tumours; (ii) its ability to potentiate chemotherapy, as described with other immunotherapeutics; or (iii) the immune mechanisms by which its anti-tumour activity is mediated. Moreover, no human clinical studies on the potential chemopreventive effect have been done so far.

As discussed above, it appears that like the other biological functions of LF, its anti-tumour role is complex (Ward et al., 2005).

Several researchers suggested a direct effect of LF on tumour cell growth based on the fact that both LF and a splice variant are downregulated or absent in many cancer cell lines and in experimental tumours (Campbell et al., 1992; Panella et al., 1991; Penco et al., 1999; Teng et al., 2004; Benaissa et al., 2005; Siebert et al., 1997; Breton et al., 2004; Rossiello et al., 1984). Furthermore, Damiens and co-workers (1999) found that treatment of human breast carcinoma cells MDA-MB-231 with hLF induced growth arrest at the G1 to S transition of the cell cycle by modulating the expression and the activity of key G1 regulatory proteins, including the Cdk 
inhibitors p21 and p27, which may be mediated in part by modulation of the Akt and MAPK pathways. The reported effects of LF occur through a p53-independent mechanism both in MDA-MB-231 cells and other epithelial cell lines such as HBL-100, MCF-7, and HT-29.The same conclusions were achieved in another study using head and neck cell lines (Xiao et al., 2004). In vivo studies also suggest that the inhibition of tumour cell growth by LF may be related to the ability of this protein to induce apoptosis of cancer cells by activating the FAS signalling pathway in cancerous cells (Fujita et al., 2004a, b). Fujita and co-workers (2004a) studied the effect of LF on the gene expression of 10 apoptosis-related molecules in colon mucosa of azoxymethane (AOM)-treated rats during early and late stages of colon carcinogenesis and found that FAS and pro-apoptotic BCL-2 members participate in the LF action and may contribute to suppressive effects on tumour development in the rat colon. Additionally, they studied (Fujita et al., 2004b) the influence of bLF on FAS-mediated apoptosis with regard to expression of FAS, activation of caspase-8 and caspase-3, and DNA fragmentation in the colon mucosa of AOM-treated rats and the results confirmed the suggestion that apoptosis caused by elevated expression of FAS is involved in chemoprevention by LF in colon carcinogenesis.

LF was also found to stimulate the production and activation of several immune cells, including lymphocytes and NK cells (Legrand et al., 2004; Horwitz et al., 1984; Shau et al., 1992), in addition to increasing the target cell sensitivity to NK lysis (Damiens et al., 1998), thus immunomodulation may be critical to the anti-tumour role of LF. Damiens and co-workers (1998) investigated LF involvement, at inflammatory concentrations, in cancer progression. They reported that LF has a significant effect on NK cell cytotoxicity against haematopoietic and breast epithelial cell lines. By pre-treatment of either NK cells or target cells with LF, it was demonstrated that the LF effect is due both to a modulation of NK cell cytotoxicity and the target cell sensitivity to lysis. Moreover, LF was found to exert an effect on target cells depending on the cell phenotype, i.e. it does not modify the susceptibility to lysis of haematopoietic cells such as Jurkat and K-562 cells, but does significantly increase that of the 
breast and colon epithelial cells. Ultimately, it was demonstrated that LF inhibits epithelial cell proliferation by blocking the cell cycle progression.

Marked inhibition of tumour growth and reduced lung colonization by B16-F10 melanoma experimental metastasis were found in mice treated with hLF injected intraperitoneal as a result of an enhanced NK cell activity (Bezault et al., 1994). Moreover, it has been shown that the protective effect of oral administration of LF in several rodent cancer models is associated with enhancement of the local intestinal mucosal immune response. In this regard, upregulation and/or enhanced activation of NK cells, CD4+ T lymphocytes and CD8+ T-lymphocytes were observed upon LF administration (Wang et al., 2000; Iigo et al., 1999; Kuhara et al., 2000). A low absorption of LF from the intestine was reported, nevertheless an enhancement of the systemic immune response was also observed.

Some authors proposed that the mechanism implicated in the protective effect of LF against cancer cell development is mediated by IL-18 (Reddy, 2004), as LF was found to strongly regulate IL-18 expression in intestinal epithelium (Iigo et al., 2004; Varadhachary et al., 2004; Kuhara et al., 2000). Finally, LF was also shown to inhibit tumour-initiated angiogenesis in vitro and in vivo, which may relate to the anti-angiogenic properties of IL-18 (Shimamura et al., 2004; Yoo et al., 1997a; Cao et al. 1999; Norrby, 2004), LF was found to participate as a regulator of angiogenesis, possibly by blocking endothelial function and inducing IL-18 production.

\section{PRODUCTION OF LACTOFERRIN AND ITS DERIVATIVES}

Many methods of isolating LF from milk have been reported (Groves, 1960; Johansson, 1969; Law and Reiter, 1977; Wakabayashi et al., 2006), but it is quite difficult to scale up an experimental method to achieve industrial production. There are many problems involved in the manufacture of high-purity LF, including the need for mass production, reuse of the residual milk materials after isolation of LF, a comparatively simple manufacturing process, and high levels of stability and sanitation of the plant equipment. Nowadays, high-purity LF is obtainable 
on a laboratory scale using gel filtration chromatography (Al-Mashikhi and Nakai, 1987), immobilized monoclonal antibodies (Kawakami et al., 1987), chelating chromatography (AlMashikhi et al., 1988), hydrophobic interaction chromatography, Cibacron Blue affinity chromatography (Shimazaki and Nishio, 1991), immunoaffinity chromatography (Noppe et al. 2006), carboxymethyl cation exchange chromatography (Yoshida and Ye, 1991; Elagamy et al., 1996), cation exchange membranes (Chiu and Etzel, 1997), adsorptive membrane chromatography (Plate et al., 2006), simulated moving bed technology (Andersson and Mattiasson 2006), semi-batch foaming process (Saleh and Hossain, 2001), and microfiltration affinity purification (Chen and Wang, 1991). However, none of these techniques has been used at commercial scales because of high processing costs (Zydney, 1998).

Recently, an approach of industrial isolation and purification of bovine LF (approximately 2030 ton annually worldwide) from cheese whey and skim milk was reported (Tamura, 2004). The concentration of LF in cheese whey is roughly $100 \mathrm{mg} / \mathrm{L}$ and about 100-400 mg/l in bovine milk. Since LF exists as a cationic protein in milk and whey, it is readily adsorbed to a cationexchange resin and then eluted using salt solutions. The eluted crude LF is then desalted and concentrated using ultrafiltration and diafiltration membranes, after which it is subjected to pasteurization. Purified LF powder with a purity of 95\% or higher is finally obtained by freezedrying (Tomita et al., 2002). In an alternative process, microfiltration and spray-drying are performed instead of pasteurization and freeze-drying, respectively. While making efforts to develop a practical method for the pasteurization of LF, Abe and co-workers (1991) found that LF is stable against heat treatment under acidic conditions, while heat treatment at a neutral $\mathrm{pH}$ causes denaturation of the protein. It is considered that heating at a $\mathrm{pH}$ above 4 and to a temperature of $90-100^{\circ} \mathrm{C}$ for $5-10 \mathrm{~min}$ as well as the UHT method are suitable and practical methods for the pasteurization of LF. This pasteurization process was patented, and it has been applied to the manufacture of a wide variety of commercial products containing LF. Additionally, LF was also isolated from bovine colostrum by ultrafiltration and then purified with a fast flow strong cation exchange chromatography system in a production scale (Lu et al., 2007). Processes involving chromatography have some limitations at industrial scale such as 
high cost and relatively low throughputs. Membrane filtration could represent an interesting alternative to chromatography for LF fractionation as membrane processes are already well integrated in the dairy industry. However, fouling and poor selectivity in protein separation have been associated with such membrane filtration processes. Different strategies have been investigated to overcome limitations associated with LF separation by membrane filtration including variation of the hydrodynamic parameters (Chilukuri et al., 2001), modification of the physico-chemical environment (Chaufer et al., 2000; Rabiller-Baudry et al., 2001; Brisson et al., 2007), use of different membrane types (Mehra and Donnelly, 1993; Ulber et al., 2001) and alteration of the membrane surface properties (Rabiller-Baudry et al., 2001).

Regarding LF derivatives, a pepsin hydrolysate of LF was produced by treatment with porcine pepsin under acidic conditions (Saito et al. 1991). After hydrolysis has been completed, pepsin was inactivated by heat treatment. Then the reaction mixture was filtered and concentrated by reverse osmosis. Finally, the hydrolysate of LF was obtained by pasteurization and freezedrying for use in infant formula. In addition, lactoferricin can be purified from this LF hydrolysate by two-step hydrophobic chromatography (Bellamy et al., 1992). The peptide is eluted with an acidic buffer, the eluted solution is concentrated by reverse osmosis, and finally, lactoferricin is produced by freeze-drying as a powder with over 95\% purity. This production process for lactoferricin has also been patented. The toxicity of purified LF was judged to be extremely low in safety tests. From the results of single-dose, 4-week, and 13-week oral toxicity tests, the dose of LF that caused no adverse effects was found to be $2000 \mathrm{mg} . / \mathrm{kg} /$ day for rats of both sexes (Yamauchi et al., 2000a). In addition, LF did not exhibit any mutagenic potential in a bacterial reverse-mutation test (Yamauchi et al. 2000b). Based on the results of these safety tests and the results of clinical studies, purified LF is considered to be a highly safe food additive. Along with increased recognition of the biological effects of LF, as described below, the applications of LF have been expanded. LF-supplemented infant formula, follow-up milk, skim milk, yogurt, chewing gum, and nutritional supplements are being marketed. In addition to foods, LF is also used in skin care cosmetics, in special therapeutic diets for the relief of inflammation in dogs and cats, and in aquaculture feed (Wakabayashi et al., 2006). 


\section{CONCLUSION}

Evidence that diet is a key environmental factor affecting the incidence of many chronic diseases is overwhelming. Indeed, several food derived compounds we eat are among the most promising chemopreventive agents being evaluated. To this regard, the use of naturally occurring compounds, like for instance LF, is advantageous because most of them are ingested routinely as food components and therefore they are safe. Nevertheless, the approval of a new chemopreventive agent requires the development of appropriate in vivo animal assay systems to provide reliable information regarding organotropism and adverse effects.

A host of interesting features of LF, namely its role on iron homeostasis, organ morphogenesis and host defence against infection, inflammation and cancer, have led to a wide range of potential applications in the medical field. Distinct mechanisms of action have been described for each LF's functions which possibly work in concert to potentiate its biological effect in vivo. LF presents the capacity to bind to a broad variety of epithelial and immune cells, which probably confers this protein the ability to regulate cellular signalling pathways and consequently exert its protective functions, for example against cancer. Nevertheless, further investigations on the cellular localization and downstream molecular events that follow LF engagement with these receptors are needed. The protective effect of LF against chemically induced carcinogenesis, tumour growth and/or metastasis have been demonstrated in an increasing number of animal model studies, therefore suggesting its great potential therapeutic use in cancer disease prevention and/or treatment. However, much available data has been derived from studies where high doses of non homologous LF of unknown purity were used and to which the tissues in our bodies may never be exposed, therefore all extrapolations require a careful interpretation of the results.

Finally, despite the evidence that LF possesses chemopreventive activity, its anti-cancer activity against established tumours, ability to potentiate chemotherapy as described with other 
immunotherapeutics, and the immune mechanisms by which its anti-tumour activity is mediated, is still largely unknown.

\section{ACKNOWLEDGEMENT}

The F.C.T. (Fundação para a Ciência e a Tecnologia) provided financial support for L.

Rodrigues through a post doctoral research grant SFRH/BPD/26064/2005.

\section{REFERENCES}

Abe, H., Saito, H., Miyakawa, H., Tamura, Y., Shimamura, S., Nagao, E., and Tomita, M. 1991. Heat stability of bovine lactoferrin at acidic pH. J. Dairy Sci. 74: 65-71.

Adamik, B., Zimecki, M., Wlaszczyk, A., Berezowicz, P. and Kubler, A. 1998 Lactoferrin effects on the in vitro immune response in critically ill patients. Arch. Immunol. Ther. Exp. (Warsz). 46:169-176.

Al-Mashikhi, S.A. and Nakai, S. 1987. Isolation of bovine immunoglobulins and lactoferrin from whey proteins by gel filtration technique. J. Dairy Sci. 70: 2486-2492.

Al-Mashikhi, S.A., Li-Chan, E. and Nakai, S. 1988. Separation of immunoglobulins and lactoferrin from cheese whey by chelating chromatography. J. Dairy Sci. 71: 1747-1755.

Al-Nabulsi, A.A. and Holley, R.A. 2006. Enhancing the antimicrobial effects of bovine lactoferrin against Eschericia coli O157:H7 by cation chelation, $\mathrm{NaCl}$ and temperature. J. Appl. Microbiol. 100: 244255.

Ammendollia, M.G., Pietrantoni, A., Tinari, A., Valenti, P. and Superti, F. 2007. Bovine lactoferrin inhibits echovirus endocytic pathway by interacting with viral structural polypeptides. Antiviral Res. 73 (3): 151-160.

Andersen, J.H., Osbakk, S.A., Vorland, L.H., Traavik, T. and Gutteberg, T.J. 2001 Lactoferrin and cyclic lactoferricin inhibit the entry of human cytomegalovirus into human fibroblasts. Antiviral Res. 51:141-149.

Andersson, J. and Mattiasson, B. 2006. Separation of lactoperoxidase and lactoferrin from whey protein concentrate. J Chromatogr A 1107 (1-2): 88-95.

Babina, S.E., Tuzikov, F.V., Tuzikova, N.A., Buneva, V.N. and Nevinskii, G.A. 2006. The effect of nucleotides on oligomeric state of human lactoferrin. Mol. Biol. (Mosk.) 40: 137-149.

Baker, E.N. 1994 Structure and reactivity of transferrins. Adv. Inorg. Chem. 41: 389-463.

Baker, E.N. and Baker, H.M. 2005 Molecular structure, binding properties and dynamics of lactoferrin. Cell. Mol. Life Sci. 62:2531-2539.

Baker, E.N., Baker, H.M. and Kidd, R.D. 2002 Lactoferrin and transferrin: Functional variations on a common structural framework. Biochem. Cell Biol. 80:27-34.

Baumrucker, C.R., Schanbacher, F., Shang, Y. and Green, M.H. 2006. Lactoferrin interaction with retinoid signalling: cell growth and apoptosis in mammary cells. Dom. Animal End. 30 (4): 289-303.

Baveye, S., Elass, E., Mazurier, J., Spik, G. and Legrand, D. 1999 Lactoferrin: a multifunctional glycoprotein involved in the modulation of the inflammatory process. Clin. Chem. Lab. Med. 37:281286.

Bellamy, W., Takase, M., Yamauchi, K., Wakabayashi, H., Kawase, K. and Tomita, M. 1992 Identification of the bactericidal domain of lactoferrin. Biochim. Biophys. Acta 1121:130-136.

Benaissa, M., Peyrat, J.P., Hornez, L., Mariller, C., Mazurier, J. and Pierce, A. 2005 Expression and prognostic value of lactoferrin mRNA isoforms in human breast cancer. Int. J. Cancer 114:299-306.

Bennett, R.M. and Davis, J. 1981 Lactoferrin binding to human peripheral blood cells: an interaction with a B-enriched population of lymphocytes and a subpopulation of adherent mononuclear cells. $J$. Immunol. 127:1211-1216.

Berliner, N., Hsing, A., Graubert, T., Sigurdsson, F., Zain, M., Bruno, E. and Hoffman, R. 1995 Granulocyte colony-stimulating factor induction of normal human bone marrow progenitors results in neutrophil-specific gene expression. Blood 85:799-803. 
Berlutti, F., Schippa, S., Morea, C., Sarli, S., Perfetto, B., Donnarumma, G. and Valenti, P. 2006. Lactoferrin downregulates pro-inflammatory cytokines upexpressed in intestinal epithelial cells infected with invasive or non-invasive Escherichia coli strains. Biochem. Cell Biol. 84: 351-357.

Bezault, J., Bhimani, R., Wiprovnick, J. and Furmanski, P. 1994 Human lactoferrin inhibits growth of solid tumors and development of experimental metastases in mice. Cancer Res. 54:2310-2312.

Birgens, H.S., Karle, H., Hansen, N.E. and Ostergaard Kristensen, L. 1984 Lactoferrin receptors in normal and leukaemic human blood cells. Scand. J. Haematol. 33:275-280.

Birgens, H.S., Kristensen, L.O., Borregaard, N., Karle, H. and Hansen, N.E. 1988 Lactoferrin-mediated transfer of iron to intracellular ferritin in human monocytes. Eur. J. Haematol. 41:52-57.

Bowman, B.H., Yang, F.M. and Adrian, G.S. 1988 Transferrin: evolution and genetic regulation of expression. Adv. Genet. 25:1-38.

Breton, M., Mariller, C., Benaissa, M., Caillaux, K., Browaeys, E., Masson, M., Vilain, J.-P., Mazurier, J. and Pierce, A. 2004 Expression of delta-lactoferrin induces cell cycle arrest. Biometals 17:325-329.

Brisson, G., Britten, M. and Pouliot, Y. 2007. Electrically-enhanced crossflow microfiltration for separation of lactoferrin from whey protein mixtures. J. Membrane Sci. 297:206-216.

Britigan, B. E., Serody, J. S. and Cohen, M. S. 1994 The role of lactoferrin as an anti-inflammatory molecule. Adv. Exp. Med. Biol. 357:143-156.

Britigan, B.E., Lewis, T.S., Waldschmidt, M., McCormick, M.L. and Krieg, A.M. 2001 Lactoferrin binds CpG-containing oligonucleotides and inhibits their immunostimulatory effects on human B cells. $J$. Immunol. 167:2921-2928.

Brock, J.H. 1980 Lactoferrin in human milk: its role in iron absorption and protection against enteric infection in the newborn infant. Arch. Dis. Child. 55:417-421.

Brock, J.H. 2002 The physiology of lactoferrin. Biochem. Cell Biol. 80:1-6.

Bullen, J.J., Rogers, H.J., Spalding, P.B. and Ward, C.G. 2006. Natural resistance, iron and infection: a challenge for clinical medicine. J. Med. Microbiol. 55: 251-258.

Campbell, T., Skilton, R.A., Coombes, R.C., Shousha, S., Graham, M.D. and Luqmani, Y.A. 1992 Isolation of a lactoferrin cDNA clone and its expression in human breast cancer. Br. J. Cancer 65:1926.

Cao, R., Farnebo, J., Kurimoto, M. and Cao, Y. 1999 Interleukin-18 acts as an angiogenesis and tumor suppressor. FASEB J. 13:2195-2202.

Castellino, F.J., Fish, W.W. and Mann, K.G. 1970 Strutural studies on bovine lactoferrin. J. Biol. Chem. 245:4269-4275.

Chaufer, B., Rabiller-Baudry, M., Lucas, D., Michel, F. and Timmer, M. 2000. Selective extraction of lysozyme from a mixture with lactoferrin by ultrafiltration. Role of the physico-chemical environment, Lait 80: 197-203.

Chen, J.P. and Wang, C.H. 1991. Microfiltration affinity purification of lactoferrin and immunoglobulins from cheese whey. J. Food Sci. 56:701-706.

Chilukuri, V.V.S., Marshall, A.D., Munro, P.A. and Singh, H. 2001. Effect of sodium dodecyl sulphate and cross-flow velocity on membrane fouling during cross-flow microfiltration of lactoferrin solutions. Chem. Eng. Process 40: 321-328.

Chiu, C.K. and Etzel, M.R. 1997. Fractionation of lactoperoxidase and lactoferrin from bovine whey using a cation exchange membrane. J. Food Sci. 62: 996-1000.

Cho E, Smith-Warner SA, Spiegelman D, Beeson, W.L., van den Brandt, P.A., Colditz, G.A., Folsom, A.R., Fraser, G.E., Freudenheim, J.L., Giovannucci, E., Goldbohm, R.A., Graham, S., Miller, A.B., Pietinen, P., Potter, J.D., Rohan, T.E., Terry, P., Toniolo, P., Virtanen, M.J., Willett, W.C., Wolk, A., Wu, K., Yaun, S-S., Zeleniuch-Jacquotte, A. and Hunter, D.J. 2004 Dairy foods, calcium, and colorectal cancer: a pooled analysis of 10 cohort studies. J. Natl. Cancer Inst. 96:1015-1022.

Close, M.J., Howlett, A.R., Roskelley, C.D., Desprez, P.Y., Bailey, N., Rowning, B., Teng, C.T., Stampfer, M.R. and Yaswen, P. 1997 Lactoferrin expression in mammary epithelial cells is mediated by changes in cell shape and actin cytoskeleton. J. Cell. Sci. 110:2861-2871.

Crouch, S.P., Slater, K.J. and Fletcher, J. 1992 Regulation of cytokine release from mononuclear cells by the iron-binding protein lactoferrin. Blood 80:235-240.

Damiens, E., El Yazidi, I., Mazurier, J., Duthille, I., Spik, G. and Boilly-Marer, Y. 1999 Lactoferrin inhibits G1 cyclin-dependent kinases during growth arrest of human breast carcinoma cells. J. Cell. Biochem. 74:486-498.

Damiens, E., Mazurier, J., El Yazidi, I., Masson, M., Duthille, I., Spik, G. and Boilly-Marer, Y. 1998 Effects of human lactoferrin on NK cell cytotoxicity against haematopoietic and epithelial tumour cells. Biochim. Biophys. Acta 1402:277-287.

Das, P., Tiwari, G., Rupa, P. and Garg, L.C. 1999 Molecular cloning and sequence analysis of bubaline lactoferrin promoter. DNA Seq. 10:97-99. 
Das, S.K., Taylor, J.A., Korach, K.S., Paria, B.C., Dey, S.K. and Lubahn, D.B. 1997 Estrogenic responses in estrogen receptoralpha deficient mice reveal a distinct estrogen signalling pathway. Proc. Natl. Acad. Sci. U.S.A. 94:12786-12791.

Davis, C. and Milner, J. 2004 Frontiers in nutrigenomics, proteomics, metabolomics and cancer prevention. Mutat. Res. 551:51-64.

Desai, D., Faubion, W.A. and Sandborn, W.J. 2007. Biological activity markers in inflammatory bowel disease. Aliment. Pharmacol. Ther. 25: 247-255.

Dhennin-Duthille, I., Masson, M., Damiens, E., Fillebeen, C., Spik, G. and Mazurier, J. 2000 Lactoferrin upregulates the expression of CD4 antigen through the stimulation of the mitogen activated protein kinase in the human lymphoblastic T Jurkat cell line. J. Cell. Biochem. 79:583-593.

Di Mario, F., Aragona, G., Dal Bo, N., Cavestro, G.M., Cavallaro, L., Iori, V., Comparato, G., Leandro, G., Pilotto, A. and Franze, A. 2003 Use of bovine lactoferrin for Helicobacter pylori eradication. Dig. Liver Dis. 35:706-710.

Elagamy, E.I., Ruppanner, R., Ismail, A., Champagne, C.P. and Assaf, R. 1996. Purification and characterization of lactoferrin, lactoperoxidase, lysozyme and immunoglobulins from camel's milk. Int. Dairy J. 6: 129-145.

Elliot, R. and Ong, T. 2002 Nutritional genomics. Br. Med. J. 324:1438-1442.

Elliott, R.L., Elliott, M.C., Wang, F. and Head, J.F. 1993 Breast carcinoma and the role of iron metabolism. A cytochemical, tissue culture, and ultrastructural study. Ann. N. Y. Acad. Sci. 698:159166.

Ellison, R.T. III. and Giehl, T.J. 1991 Killing of Gram-negative bacteria by lactoferrin and lysozyme. J. Clin. Invest. 88:1080-1091.

Faulk, W.P., Hsi, B.L. and Stevens, P.J. 1980 Transferrin and transferrin receptors in carcinoma of the breast. Lancet 2:390-392.

Fischer, R., Debbabi, H., Dubarry, M., Boyaka, P. and Tome, D. 2006. Regulation of physiological and pathological Th1 and Th2 responses by lactoferrin. Biochem. Cell Biol. 84: 303-311.

Forozan, F., Mahlamaki, E. H., Monni, O., Chen, Y., Veldman, R., Jiang, Y., Gooden, G.C., Ethier, S.P., Kallioniemi, A. and Kallioniemi, O.- 2000 Comparative Genomic Hybridization Analysis of 38 Breast Cancer Cell Lines: A Basis for Interpreting Complementary DNA Microarray Data1. Cancer Res. 60: 4519-4525.

Frydecka, I., Zimecki, M., Bocko, D., Kosmaczewska, A., Teodorowska, R., Ciszak, L., Kruzel, M., Wlodarska-Polinska, J., Kuliczkowski, K. and Kornafel, J. 2002 Lactoferrin-induced up-regulation of zeta chain expression in peripheral blood $\mathrm{T}$ lymphocytes from cervical cancer patients. Anticancer Res. 22:1897-1901.

Fujita, K., Matsuda, E., Sekine, K., Iigo, M. and Tsuda H. 2004a Lactoferrin modifies apoptosis-related gene expression in the colon of the azoxymethane-treated rat. Cancer Lett. 213:21-29.

Fujita, K., Matsuda, E., Sekine, K., Iigo, M. and Tsuda, H. 2004b Lactoferrin enhances Fas expression and apoptosis in the colon mucosa of azoxymethane-treated rats. Carcinogenesis 25:1961-1966.

Fujita, K., Ohnishi, T., Sekine, K., Iigo, M. and Tsuda H. 2002 Down-regulation of 2-amino-3,8dimethylimidazo[4,5-f] quinoxaline (MeIQx)-induced CYP1A2 expression is associated with bovine lactoferrin inhibition of MeIQx-induced liver and colon carcinogenesis in rats. Jpn. J. Cancer Res. 93:616-625.

Furmanski, P., Li, Z.P., Fortuna, M.B., Swamy, C.V. and Das, M.R. 1989 Multiple molecular forms of human lactoferrin. Identification of a class of lactoferrins that possess ribonuclease activity and lack iron-binding capacity. J. Exp. Med. 170:415-429.

Geng, K., Li, Y., Bezault, J. and Furmanski, P. 1998 Induction of lactoferrin expression in murine ES cells by retinoic acid and estrogen. Exp. Cell Res. 245:214-220.

Ghio, A.J., Zhang, J. and Piantadosi, C.A. 1992 Generation of hydroxyl radical by crocidolite asbestos is proportional to surface [Fe3+]. Arch. Biochem. Biophys. 298:646-650.

Giancotti, V. 2006. Breast cancer markers. Cancer Lett. 243: 145-159.

Giansanti, F., Rossi, P., Massucci, M.T., Botti, D., Antonini, G., Valenti, P. and Seganti, L. 2002 Antiviral activity of ovotransferrin discloses an evolutionary strategy for the defensive activites of lactoferrin. Biochem. Cell Biol. 80:125-130.

Gill, H.S. and Cross, M.L. 2000 Anticancer properties of bovine milk. Br. J. Nutr. 84:S161-S166.

Giuffre, G., Arena, F., Scarfi, R., Simone, A., Todaro, P. and Tuccari, G. 2006. Lactoferrin immunoexpression in endometrial carcinomas: relationships with sex steroid hormone receptors (ER and PR), proliferation indices (Ki-67 and AgNOR) and survival. Oncology Rep. 16: 257-263.

Goodman, S.A. and Young, L.G. 1981 Immunological identification of lactoferrin as a shared antigen on radioiodinated human sperm surface and in radioiodinated human seminal plasma. J. Reprod. Immunol. 3:99-108. 
Goretzki, L. and Mueller, B.M. 1998 Low-density-lipoprotein receptor-related protein (LRP) interacts with a GTP-binding protein. Biochem. J. 336:381-386.

Grant, D.J., Shi, H. and Teng, C.T. 1999 Tissue and site-specific methylation correlates with expression of the mouse lactoferrin gene. J. Mol. Endocrinol. 23:45-55.

Green, M.R. and Pastewka, J.V. 1978 Lactoferrin is a marker for prolactin response in mouse mammary explants. Endocrinology 103:151-103.

Groves, M.L. 1960. The isolation of a red protein from milk. J. Am. Chem. Soc. 82: 3345-3350.

Hangoc, G., Falkenburg, J.H.F. and Broxmeyer, H.E. 1991 Influence of T-lymphocytes and lactoferrin on the survival-promoting effects of IL-1 and IL-6 on human bone marrow granulocyte-macrophage and erythroid progenitor cells. Exp. Hematol. 19:697-703.

Hekman, A. and Rumke, P. 1969 The antigens of human seminal plasma with special reference to lactoferrin as a spermatozoacoating antigen. Fertil. Steril. 20:312-323.

Hirata, I., Hoshimoto, M., Saito, O., Kayazawa, M., Nishikawa, T., Murano, M., Toshina, K., Wang, F.Y. and Matsuse, R. 2007. Usefulness of faecal lactoferrin and haemoglobin in diagnosis of colorectal diseases. World J. Gastroenterol. 13(10): 1569-1574.

Horwitz, D.A., Bakke, A.C., Abo, W. and Nishiya, K. 1984 Monocyte and NK cell cytotoxic activity in human adherent cell preparations: discriminating effects of interferon and lactoferrin. J. Immunol. 132:2370-2374.

Hu, W.L., Regoeczi, E., Chindemi, P.A. and Bolyos, M. 1993 Lactoferrin interferes with uptake of iron from transferrin and asialotransferrin by the rat liver. Am. J. Physiol. 264:112-117.

Hutchens, T.W., Henry, J.F., Yip, T.T., Hachey, D.L., Schanler, R.J., Motil, K.J. and Garza, C. 1991 Origin of intact lactoferrin and its DNA binding fragments found in the urine of human milk-fed preterm infants. Evaluation by stable isotopic enrichment. Pediatr. Res. 29:243-250.

Iigo, M., Kuhara, T., Uchida, Y., Sekine, K., Moore, M.A. and Tsuda, H. 1999 Inhibitory effects of bovine lactoferrin on colon carcinoma 26 lung metastasis in mice. Clin. Exp. Metastasis 17:35-40.

Iigo, M., Shimamura, M., Matsuda, E., Fujita, K., Nomoto, H., Satoh, J., Kojima, S, Alexander, D.B., Moore, M.A. and Tsuda, H. 2004 Orally administered bovine lactoferrin induces caspase-1 and interleukin-18 in the mouse intestinal mucosa: a possible explanation for inhibition of carcinogenesis and metastasis. Cytokine 25:36-44.

Ikeda, M., Nozaki, A., Sugiyama, K., Tanaka, T., Naganuma, A., Tanaka, K., Sekihara, H., Shimotohno, K., Saito, M. and Kato, N. 2000 Characterization of antiviral activity of lactoferrin against hepatitis C virus infection in human cultured cells. Virus Res. 66:51-63.

Ismail, M. and Brock, J.H. 1993 Binding of lactoferrin and transferrin to the human promonocytic cell line U937. J. Biol. Chem. 268:21618-21625.

Iwasa, M., Kaito, M., Ikoma, J., Takeo, M., Imoto, I., Adachi, Y., Yamauchi, K., Koizum, R. and Teraguchi, S. 2002 Lactoferrin inhibits hepatitis C virus viremia in chronic hepatitis C patients with high viral loads and HGV genotype 1b. Am. J. Gastroenterol. 97:766-767.

Iyer, S. and Lonnerdal, B. 1993 Lactoferrin, lactoferrin receptors and iron metabolism. Eur. J. Clin. Nutr. 47:232-241.

Johanson, B. 1960 Isolation of an iron-containing red protein from human milk. Acta Chem. Scand. 14:510-512.

Johansson, B.G. 1969. Isolation of crystalline lactoferrin from human milk. Acta Chem. Scand. 23:683684.

Jordan, V.C. and Morrow, M. 1999 Tamoxifen, raloxifene and the prevention of breast cancer. Endocr. Rev. 20:253-278.

Kahler, S., Christophers, E. and Schroder, J.M. 1988 Plasma lactoferrin reflects neutrophil activation in psoriasis. Br. J. Dermatol. 119:289-293.

Katsuaki, T. 2006. Functionalities and usefulness of lactoferrins (2) Clinical application of lactoferrin for the treatment of chronic hepatitis C. Foods \& Food Ingred J Jpn 211 (9): 748-753.

Kawakami, A., Hirayama, K., Kawakami, F., Kawakami, H., Fujihara, M. and Ohtsuki, K. 2006. Purification and biochemical characterization of fibroblast growth factor-binding protein (FGF-BP) from the lactoferrin fraction of bovine milk. Biochim. Biophys. Acta 1760: 421-431.

Kawakami, H., Dosako, S. and Nakajima, I. 1993 Effect of lactoferrin on iron solubility under neutral conditions. Biochemistry 57:1376-1377.

Kawakami, H., Shinmoto, H., Dosako, S. and Sogo, Y. 1987. One-step isolation of lactoferrin using immobilized monoclonal antibodies. J. Dairy Sci. 70: 752-759.

Khanna-Gupta, A., Zibello, T., Simkevich, C., Rosmarin, A.G. and Berliner, N. 2000 Sp1 and C/EBP are necessary to activate the lactoferrin gene promoter during myeloid differentiation. Blood 95:37343741. 
Kim, C.W., Son, K.-N., Choi, S.-Y. and Kim, J. 2006. Human lactoferrin upregulates expression of KDR/Flk-1 and stimulates VEGF-A-mediated endothelial cell proliferation and migration. FEBS Lett. 580: 4332-4336.

Kim, S.J., Yu, D.Y., Pak, K.W., Jeong, S., Kim, S.W. and Lee, K.K. 1998 Structure of the human lactoferrin gene and its chromosomal localization. Mol. Cells 8: 663-668.

Klintworth, G.K., Sommer, J.R., Obrian, G., Han, L., Ahmed, M.N., Qumsiyeh, M.B., Lin, P.Y., Basti, S., Reddy, M.K., Kanai, A., Hotta, Y., Sugar, J., Kumaramanickavel, G., Munier, F., Schorderet, D.F., Matri, L.E., Iwata, F., Kaiser-Kupfer, M., Nagata, M., Nakayasu, K., Hejtmancik, J.F. and Teng, C.T. 1997 Familial subepithelial corneal amyloidosis (gelationous drop-like corneal dystrophy): exclusion of linkage to lactoferrin gene. Mol. Vis. 38:31-38.

Konishi, M., Iwasa, M., Yamauchi, K., Sugimoto, R., Fujita, N., Kobayashi, Y., Watanabe, S., Teraguchi, S., Adachi, Y. and Kaito, M. 2006. Lactoferrin inhibits lipid peroxidation in patients with chronic hepatitis C. Hepatology Res. 36 (1): 27-32.

Kruzel, M.L., Bacsi, A., Choudhury, B., Sur, S. and Boldogh, I. 2006. Lactoferrin decreases pollen antigen-induced allergic airway inflammation in a murine model of asthma. Immunology 119:159166.

Kuhara, T., Iigo, M., Itoh, T., Ushida, Y., Sekine, K., Terada, N., Okamura, H. and Tsuda, H. 2000 Orally administered lactoferrin exerts an anti metastatic effect and enhances production of IL-18 in the intestinal epithelium. Nutr. Cancer 38:192-199.

Kuhara, T., Yamauchi, K., Tamura, Y. and Okamura, H. 2006. Oral administration of lactoferrin increases NK cell activity in mice via increased production of IL-18 and type I IFN in the small intestine. J. Interferon Cytokine Res. 26 (7): 489-499.

Kuwata, H., Yamauchi, K., Teraguchi, S., Ushida, Y., Shimokawa, Y., Toida, T. and Hayasawa, H. 2001 Functional fragments of ingested lactoferrin are resistant to proteolytic degradation in the gastrointestinal tract of adult rats. J. Nutr. 131:2121-2127.

Kuwata, H., Yip, T.T., Tomita, M. and Hutchens, T.W. 1998a Direct evidence of the generation in human stomach of an antimicrobial peptide domain (lactoferricin) from ingested lactoferrin. Biochim. Biophys. Acta 1429:129-141.

Kuwata, H., Yip, T.T., Yamauchi, K., Teraguchi, S., Hayasawa, H., Tomita, M. and Hutchens, T.W. $1998 \mathrm{~b}$ The survival of ingested lactoferrin in the gastrointestinal tract of adult mice. Biochem. J. 334:321-323.

Lampreave, F., Pineiro, A., Brock, J.H., Castillo, H., Sanchez, L. and Calvo, M. 1990 Interaction of bovine lactoferrin with other proteins of milk whey. Int. J. Biol. Macromol. 12:2-5.

Larkins, N. 2005. Potential implications of lactoferrin as a therapeutic agent. Am. J. Vet. Res. 66: 739742.

Law, B.A. and Reiter, B. 1977. The isolation and bacteriostatic properties of lactoferrin from bovine milk whey. J. Dairy Res. 44:595-561.

Lee, H.Y., Park, J.H., Seok, S.H., Back, M.W., Kim, D.J., Lee, B.H., Kang, P.D., Kim, Y.S. and Park, J.H. 2005. Potential antimicrobial effects of human lactoferrin against oral infection with Listeria monocytogenes in mice. J. Med. Microbiol. 54: 1049-1054.

Legrand, D., Elass, E., Carpentier, M. and Mazurier, J. 2005. Lactoferrin: a modulator of immune and inflammatory responses. Cell Mol. Life Sci. 62: 2549-2559.

Legrand, D., Elass, E., Pierce, A. and Mazurier, J. 2004 Lactoferrin and host defence: an overview of its immuno-modulating and anti-inflammatory properties. Biometals 17:225-229.

Levay, P.F. and Viljoen, M. 1995 Lactoferrin: a general review. Haematologica 80:252-267.

Liehr, J.G. and Jones, J.S. 2001 Role of iron in estrogen-induced cancer. Curr. Med. Chem. 8:839-849.

Longhi, G., Pietropaolo, V., Mischitelli, M., Longhi, C., Conte, M.P., Marchetti, M., Tinari, A., Valenti, P., Degener, A.M., Seganti, L. and Superti, F. 2006. Lactoferrin inhibits early steps of human BK polyomavirus infection. Antiviral Res. 72 (2): 145-152.

Lönnerdal, B. 2003. Lactoferrin. In Advanced Dairy Chemistry, Vol I: Proteins. Eds. P. F. Fox and P.L.H. McSweeney. Kluwer Academic/Plenum Publishers, Norwell, MA, pp 449-466.

Lönnerdal, B. and Iyer, S. 1995 Lactoferrin: molecular structure and biological function. Annu. Rev. Nutr. 15:93-110.

Lu, R.R., Xu, S.Y., Wang, Z. and Yang, R.J. 2007. Isolation of lactoferrin from bovine colostrum by ultrafiltration coupled with strong cation exchange chromatography on a production scale. $J$. Membrane Sci. 297:152-161.

Lund, L.G. and Aust, A.E. 1990 Iron mobilization from asbestos by chelators and ascorbic acid. Arch. Biochem. Biophys. 278:61-64.

Machnicki, M., Zimecki, M. and Zagulski, T. 1993 Lactoferrin regulates the release of tumour necrosis factor alpha and interleukin 6 in vivo. Int. J. Exp. Pathol. 74:433-439. 
Maher, R.J., Cao, D., Boxer, L.A. and Petty, H.R. 1993 Simultaneous calcium dependent delivery of neutrophil lactoferrin and reactive oxygen metabolites to erythrocyte targets: evidence supporting granule-dependent triggering of superoxide deposition. Am. J. Physiol., Cell Physiol. 156:226-234.

Mann, D.M., Romm, E. and Migliorini, M. 1994 Delineation of the glycosaminoglycan-binding site in the human inflammatory response protein lactoferrin. J. Biol. Chem. 269: 2366-23667.

Masuda C., Wanibuchi H., Sekine K., Yano Y., Otani S., Kishimoto T., Tsuda, H. and Fukushima, S. 2000 Chemopreventive effects of bovine lactoferrin on N-butyl-N-(4-hydroxybutyl)nitrosamineinduced rat bladder carcinogenesis. Jpn. J. Cancer Res. 91:582-588.

Matsuda, Y., Saoo, K., Hosokawa, K., Yamakawa, K., Yokohira, M., Zeng, Y., Takeuchi, H. and Imaida, K. 2006. Post-initiation chemopreventive effects of dietary bovine lactoferrin on 4(methylnitrosamino)-1-(3-pyridyl)-1-butanone-induced lung tumorigenesis in female A/J mice. Cancer Lett. 246: 41-46.

Matsue, M., Tomita, S., Nyui, S., Matayuma, J. and Kiyosawa, I. 1994 Suppressive effects of lactoferrin on bleomycin-dependent DNA damage by the iron ion and ascorbate. Biosci. Biotechnol. Biochem. 58:67-71.

McIntosh, G.H. 1993 Colon cancer: dietary modification required for a balanced protective diet. Prev. Med. 22:767-774.

McKeown, S.T., Lundy, F.T., Nelson, J., Lockhart, D., Irwin, C.R., Cowan, C.G., Marley, J.J. 2006. The cytotoxic effects of human neutrophil peptide-1 (HNP1) and lactoferrin on oral squamous cell carcinoma (OSCC) in vitro. Oral Oncology 42 (7): 685-690.

Mehra, R.K. and Donnelly, W.J. 1993. Fractionation of whey-protein components through a large poresize, hydrophilic, cellulosic membrane. J. Dairy Res. 60: 89-97.

Metz-Boutigue, M.-H., Jolles, J., Mazurier, J., Schoentgen, F., Legrand, D., Spik, G., Montreuil, J. and Jolles, P. 1984 Human lactotransferrin: Amino acid sequence and structural comparisons with other transferrins. Eur. J. Biochem. 145:659-676.

Mikogami, T., Marianne, T. and Spik, G. 1995 Effect of intracellular iron depletion by picolinic acid on expression of the lactoferrin receptor in the human colon carcinoma subclone HT29-18-C1. Biochem. J. 308:391-397.

Min, S. and Krochta, J. 2005 Inhibition of Penicillium commune by edible whey protein films incorporating lactoferrin, lactoferrin hydrolysate, and lactoperoxidase systems. J. Food Sci. 70:87-94.

Mistry, N., Drobni, P., Naslund, J., Sunkari, V.G., Jenssen, H. and Evander, M. 2007. The antipapillomavirus activity of human and bovine lactoferricin. Antiviral Res. 75: 258-265.

Miyamoto, K., Fukutomi, T., Akashi-Tanaka, S., Hasegawa, T., Asahara, T., Sugimura, T. and Ushijima, T. 2005. Identification of 20 genes aberrantly methylated in human breast cancer. Int. J. Cancer 116: 407-414.

Miyazawa, K., Mantel, C., Lu, L., Morrison, D.C. and Broxmeyer, H.E. 1991 Lactoferrin lipopolysaccharide interactions. Effect on lactoferrin binding to monocyte/macrophage differentiated HL-60 cells. J. Immunol 146:723-729.

Mohan, K.V., Devaraj, H., Prathiba, D., Hara, Y. and Nagini, S. 2006a. Antiproliferative and apoptosis inducing effect of lactoferrin and black tea polyphenol combination on hamster buccal pouch carcinogenesis. Biochim. Biophys. Acta 1760 (10): 1536-1544.

Mohan, K.V., Kumaraguruparan, R., Prathiba, D. and Nagini S. 2006b. Modulation of xenobioticmetabolizing enzymes and redox status during chemoprevention of hamster buccal carcinogenesis by bovine lactoferrin.Nutrition 22: 940-946.

Montreuil, J., Tonnelat, J. and Mullet, S. 1960 Preparation and properties of lactotransferrin of human milk. Biochim. Biophys. Acta 45:413-421.

Moore, S.A., Anderson, B.F., Groom, C.R., Haridas, M. and Baker, E.N. 1997 Three-dimensional structure of diferric bovine lactoferrin at 2-8 A resolution. J. Mol. Biol. 274:222-236.

Naidu, A. 2002 Activated lactoferrin - a new approach to meat safety. Food Technol. 56:40-45.

Nemet, K. and Simonovits, I. 1985 The biological role of lactoferrin. Haematologia 18:3-12.

Noppe, W., Plieva, F.M., Galaev, I.Y., Vanhoorelbeke, K., Mattiasson, B. and Deckmyn, H. 2006. Purification of lactoferrin from deffated milk. J Chromatogr A 1101 (1-2): 79-85.

Norrby, K. 2004 Human apo-lactoferrin enhances angiogenesis mediated by vascular endothelial growth factor A in vivo. J. Vasc. Res. 41:293-304.

Norrby, K., Mattsby-Baltzer, I., Innocenti, M. and Tuneberg, S. 2001 Orally administrated bovine lactoferrin systematically inhibits VEGF165-mediated angiogenesis in the rat. Int. J. Cancer 91:236240.

Nuijens, J.H., van Berkel, P.H. and Schanbacher, F.L. 1996 Structure and biological actions of lactoferrin. J. Mammary Gland Biol. Neoplasia 1:285-295. 
Okada, S., Tanaka, K., Sato, T., Ueno, H., Saito, S. Okusaka, T., Sato, K. Yamamoto, S. and Kakizoe, T. 2002 Dose-response trial of lactoferrin in patients with chronic hepatitis C. Jpn. J. Cancer Res. 93:1063-1069.

Olofsson, T., Olsson, I. and Venge, P. 1977 Myeloperoxidase and lactoferrin of blood neutrophils and plasma in chronic granulocytic leukaemia. Scand. J. Haematol. 18:113-120.

Olsson, I., Lantz, M., Persson, A.M. and Arnljots, K. 1988 Biosynthesis and processing of lactoferrin in bone marrow cells, a comparison with processing of myeloperoxidase. Blood 71:441-447.

Pan, Y., Lee, A., Wan, J., Coventry, M.J., Michalski, W.P, Shiell, B. and Roginski, H. 2006. Antiviral properties of milk proteins and their derivatives. Int. Dairy J. 16: 1252-1261.

Pan, Y., Rowney, M., Guo, P. and Hobman, P. 2007. Biological properties of lactoferrin: an overview. Aust. J. Dairy Techn. 62 (1): 31-42.

Panella T.J., Liu Y.H., Huang A.T. and Teng C.T. 1991 Polymorphism and altered methylation of the lactoferrin gene in normal leukocytes, leukemic cells and breast cancer. Cancer Res. 51:3037-3043.

Penco, S., Caligo, M.A., Cipollini, G., Bevilacqua, G. and Garre C. 1999 Lactoferrin expression in human breast cancer. Cancer Biochem. Biophys. 17:163-178.

Pentecost, B.T. and Teng, C.T. 1987 Lactotransferrin is the major estrogen inducible protein of mouse uterine secretions. J. Biol. Chem. 262:10134-10139.

Perou, C.M., Jeffrey, S.S., van de Rijn, M., Rees, C.A., Eisen, M.B., Ross, D.T., Pergamenschikov, A., Williams, C.F., Zhu, S.X., Lee, J.C., Lashkari, D., Shalon, D., Brown, P.O. and Botstein, D. 1999 Distinctive gene expression patterns in human mammary epithelial cells and breast cancer. Proc. Natl. Acad. Sci. U.S.A. 96:9212-9217.

Peterson, N.A., Anderson, B.F., Jameson, G.B., Tweedie, J.W. and Baker, E.N. 2000 Crystal structure and iron-binding properties of the R210K mutant of the N-lobe of human lactoferrin: implications for iron release from transferrins. Biochemistry 39:6625-6633.

Petricoin, E. and Liotta, L. 2003 Clinical applications of proteomics. J. Nutr. 133:2476-2484.

Pierce, A., Colavizza, D., Benaissa, M., Maes, P., Tartar, A., Montreuil, J. and Spik, G. 1991 Molecular cloning and sequence analysis of bovine lactotransferrin. Eur. J. Biochem. 196:177-184.

Plate, K., Beutel, S., Buchholtz, H., Demmer, W., Fischer-Fruhholz, S., Reif, O., Ulber, R. and Scheper, T. 2006. Isolation of bovine lactoferrin, lactoperoxidase and enzymatically prepared lactoferricin from proteolytic digestion of bovine lactoferrin using adsorptive membrane chromatography. $J$. Chromatogr. A 1117:81-86.

Qiu, J., Hendrixson, D.R., Baker, E.N., Murphy, T.F., St Geme, J.W., III and Plaut, A.G. 1998 Human milk lactoferrin inactivates two putative colonization factors expressed by Haemophilus influenzae. Proc. Natl. Acad. Sci. U.S.A. 95:12641-12646.

Querinjean, P., Masson, P.L. and Heremans, J.F. 1971 Molecular weight, single-chain structure and amino acid composition of human lactoferrin. Eur. J. Biochem. 20:420-425.

Rabiller-Baudry, M., Chaufer, B., Lucas, D. and Michel, F. 2001. Ultrafiltration of mixed protein solutions of lysozyme and lactoferrin: role of modified inorganic membranes and ionic strength on the selectivity. J. Membr. Sci. 184: 137-148.

Reddy, P. 2004 Interleukin-18: recent advances. Curr. Opin. Hematol. 11:405-410.

Roberts, A.K., Chierici, R., Sawatzki, G., Hill, M. J., Volpato, S. and Vigi, V. 1992 Supplementation of an adapted formula with bovine lactoferrin: 1. Effect on the infant faecal flora. Acta Paediatr. 81:119-124.

Rochard, E., Legrand, D., Mazurier, J., Montreuil, J. and Spik, G. 1989 The N-terminal domain I of human lactoferrin binds specifically to phylohemagglutinin-stimulated peripheral blood human lymphocyte receptor. FEBS Lett. 255:201-207.

Rossiello, R., Carriero, M.V. and Giordano, G.G. 1984. Distribution of ferritin, transferring and lactoferrin in breast cancer carcinoma tissue. J. Clin Pathol. 37: 51-55

Saito, H., Miyakawa, H., Tamura, Y., Shimamura, S., and Tomita, M. 1991. Potent bactericidal activity of bovine lactoferrin hydrolysate produced by heat treatment at acidic pH. J. Dairy Sci. 74: 3724-3730.

Sakai, T., Banno, Y., Kato, Y., Nozawa, Y. and Kawaguchi, M. 2006. Pepsin-digested bovine lactoferrin induces apoptotic cell death with JNK/SAPK activation in oral cancer cells. J. Pharmacol. Sci. 98: 41-48.

Saleh, Z.S. and Hossain, M.M. 2001. A study of the separation of proteins from multi-component mixtures by a semi-batch foaming process. Chem. Eng. Process 40:371-378.

Sanchez, L., Calvo, M. and Brock, J.H. 1992 Biological role of lactoferrin. Arch. Dis. Child. 67:657-661.

Santagati, M.G., La Terra Mulle, S., Amico, C., Pistone, M., Rusciano, D. and Enea, V. 2005. Lactoferrin expression by bovine ocullar surface epithelia: a primary cell culture model to study lactoferrin gene promoter activity. Ophthalmic Res. 37: 270-278. 
Sekine, K., Ushida, Y., Kuhara, T., Iigo, M., Baba-Toriyama, H., Moore, M.A., Murakoshi, M., Satomi, Y., Nishino, H., Kakizoe, T. and Tsuda, H. 1997b Inhibition of initiation and early stage development of aberrant crypt foci and enhanced natural killer activity in male rats administered bovine lactoferrin concomitantly with azoxymethane. Cancer Lett. 121:211-216.

Sekine, K., Watanabe, E., Nakamura, J., Takasuka, N., Kim, D.J., Asamoto, M., Vladimir, K., BabaToriyama, H., Ohta, T., Moore, M.A., Masuda, M., Sugimoto, H., Nishino, H., Kakizoe, T. and Tsuda, H. 1997a Inhibition of azoxymethane initiated colon tumour by bovine lactoferrin administration in F344 rats. Jpn. J. Cancer Res. 88:523-526.

Selby, J.V. and Friedman, G.D. 1988 Epidemiologic evidence of an association between body iron stores and risk of cancer. Int. J. Cancer 41:677-682.

Senkovich, O., Cook, W.J., Mirza, S., Hollingshead, S.K., Protasevich, I.I., Brilles, D.E. and Chattopadhyay, D. 2007. Structure of a complex human lactoferrin N-lobe with pneumococcal surface protein A provides insight into microbial defense mechanism. J. Mol. Biol. 370 (4): 701-713.

Shah, N.P. 2000 Effects of milk-derived bioactives: an overview. Br. J. Nutr. 84:S3-S10.

Shan, L., He, M., Yu, M. and Qiu, C. 2002 cDNA microarray profiling of rat mammary gland carcinomas induced by 2-amino-1-methyl-6-phenylimidazo[4,5-b]pyridine and 7,12-dimethylbenz[a]anthracene. Carcinogenesis 23:1561-1568.

Shau, H., Kim, A. and Golub, S.H. 1992 Modulation of natural killer and lymphokine-activated killer cell cytotoxicity by lactoferrin. J. Leukoc. Biol. 51:343-349.

Shigeta, H., Newbold, R.R., McLachlan, J.A. and Teng, C. 1996 Estrogenic effect on the expression of estrogen receptor, COUPTF, and lactoferrin mRNA in developing mouse tissues. Mol. Reprod. Dev. 45:21-30.

Shimamura, M., Yamamoto, Y., Ashino, H., Oikawa, T., Hazato, T., Tsuda, H. and Iigo, M. 2004 Bovine lactoferrin inhibits tumor induced angiogenesis. Int. J. Cancer 111:111-116.

Shimazaki, K. 2000. Lactoferrin: A marvellous protein in milk? Animal Sci. J. 71: 329-347.

Shimazaki, K.-I. And Nishio, N. 1991. Interacting properties of bovine lactoferrin with immobilised cibacron blue f3ga in column chromatography. J. Dairy Sci. 74: 404-408.

Siciliano, R., Rega, B., Marchetti, M., Seganti, L., Antonini, G. and Valenti, P. 1999 Bovine lactoferrin peptidic fragments involved in inhibition of herpes simplex virus type 1 infection. Biochem. Biophys. Res. Commun. 264:19-23.

Siebert, P.D. and Huang, B.C. 1997 Identification of an alternative form of human lactoferrin mRNA that is expressed differentially in normal tissues and tumor-derived cell lines. Proc. Natl. Acad. Sci. U.S.A. 94:2198-2203.

Slater, K. and Fletcher, J. 1987 Lactoferrin derived from neutrophils inhibits the mixed lymphocyte reaction. Blood 69:1328-1333.

Spik, G., Coddeville, B., Mazurier, J., Bourne, Y., Cambillaut, C. and Montreuil, J. 1994 Primary and three-dimensional structure of lactotransferrin (lactoferrin) glycans. Adv. Exp. Med. Biol. 357:21-32.

Steijns, J. and van Hooijdonk, A. 2000 Occurrence, structure, biochemical properties technological characteristics of lactoferrin. Br. J. Nutr. 84:S11-S17.

Stevens, R.G., Jones, D.Y., Micozzi, M.S. and Taylor, P.R. 1988 Body iron stores and the risk of cancer. N. Engl. J. Med. 319:1047-1052.

Suzuki, Y. and Lonnerdal, B. 2002 Characterization of mammalian receptors for lactoferrin. Biochem. Cell Biol. 80:75-80.

Tamura, Y. 2004. Production and application of bovine lactoferrin. Bulletin.IDF. 389:64-68.

Tanaka, K., Ikeda, M., Nozaki, A., Kato, N., Tsuda, H., Saito, S. and Sekihara, H. 1999 Lactoferrin inhibits hepatitis C virus viremia in patients with chronic hepatitis C: A pilot study. Jpn. J. Cancer Res. 90:367-371.

Tanaka, T., Kawabata, K., Kohno, H., Honjo, S., Murakami, M., Ota, T. and Tsuda, H. 2000 Chemopreventive effect of bovine lactoferrin on 4-nitroquinoline 1-oxide-induced tongue carcinogenesis in male F344 rats. Jpn. J. Cancer Res. 91:25-33.

Teng, C. 2002 Lactoferrin gene expression and regulation: an overview. Biochem. Cell Biol. 80:7-16.

Teng, C., Gladwell, W., Raphiou, I. and Liu, E. 2004 Methylation and expression of the lactoferrin gene in human tissues and cancer cells. Biometals 17:317-323.

Teng, C.T. 2006. Factors regulating lactoferrin gene expression. Biochem. Cell Biol. 84: 263-267.

Teng, C.T., Gladwell, W., Raphiou, I. and Liu, E. 2004. Methylation and expression of the lactoferrin gene in human tissues and cancer cells. Biometals 17: 317-323.

Teng, C.T., Pentecost, B.T., Chen, Y.H., Newbold, R.R., Eddy, E.M. and McLachlan, J.A. 1989 Lactotransferrin gene expression in the mouse uterus and mammary gland. Endocrinology 124:992999. 
Teng, C.T., Pentecost, B.T., Marshall, A., Solomon, A., Bowman, B.H., Lalley, P.A. and Naylor, S.L. 1987 Assignment of the lactotransferrin gene to human chromosome 3 and to mouse chromosome 9 . Somat. Cell Mol. Genet. 13:689-693.

Teng, C.T., Walker, M.P., Bhattacharyya, S.N., Klapper, D.G., DiAugustine, R.P. and McLachlan, J.A. 1986 Purification and properties of an oestrogen-stimulated mouse uterine glycoprotein (approx. 70 kDa). Biochem. J. 240:413-422.

Teraguchi, S., Wakabayashi, H., Kuwata, H., Yamauchi, K. and Tamura, Y. 2004 Protection against infections by oral lactoferrin: evaluation in animal models. Biometals 17:231-234.

Teraguchi, S., Wakabayashi, H., Kuwata, H., Yamauchi, K. and Tamura, Y. 2004 Protection against infections by oral lactoferrin: evaluation in animal models. Biometals 17:231-234.

Tomita, M., Wakabayashi, H., Yamauchi, K., Teraguchi, S. and Hayasawa, H. 2002 Bovine lactoferrin and lactoferricin derived from milk: production and applications. Biochem. Cell Biol. 80:109-112.

Tomita, M., Wakabayashi, K., Yamauchi, K., Teraguchi, S. and Hayasawa, H. 2002. Bovine lactoferrin and lactoferricin derived from milk: production and applications. Biochem. Cell Biol. 80:109-112.

Troost, F.J., Steijns, J., Saris, W.H.M. and Brummer, R.J.M. 2001 Gastric digestion of bovine lactoferrin in vivo in adults. J. Nutr. 131:2101-2104.

Trumpler, U., Straub, P.W. and Rosenmund, A. 1989 Antibacterial prophylaxis with lactoferrin in neutropenic patients. Eur. J. Clin. Microbiol. Infect. Dis. 8:310-313.

Tsuda, H., Sekine, K., Fujita, K. and Iigo M. 2002 Cancer prevention by bovine lactoferrin and underlying mechanisms - a review of experimental and clinical studies. Biochem. Cell Biol. 80:131136.

Tsuda, H., Sekine, K., Ushida, Y., Kuhara, T., Takasuka, N., Iigo, M., Han, B.S. and Moore, M.A. 2000 Milk and dairy products in cancer prevention: focus on bovine lactoferrin. Mutat. Res. 462:227-233.

Ulber, R., Plate, K., Weiss, T., Demmer, W., Buchholz, H. and Scheper, T. 2001. Downstream processing of bovine lactoferrin from sweet whey. Acta Biotechnol. 21: 27-34.

Ushida, Y., Sekine, K., Kuhara, T., Takasuka, N., Iigo, M. and Tsuda, H. 1998 Inhibitory effects of bovine lactoferrin on intestinal polyposis in the ApcMin mouse. Cancer Lett. 134:141-145.

Ushida, Y., Sekine, K., Kuhara, T., Takasuka, N., Iigo, M., Maeda, M. and Tsuda, H. 1999 Possible chemopreventive effects of bovine lactoferrin on esophagus and lung carcinogenesis in the rat. Jpn. J. Cancer Res. 90:262-267.

Valenti, P., Marchetti, M., Superti, F., Amendolia, M.G., Puddu, P., Gessani, S., Borghi, P., Belardelli, F., Antonini, G. and Seganti, L. 1998 Antiviral activity of lactoferrin. Adv. Exp. Med. Biol. 443:199-203.

Van Berkel, P.H.C., Geerts, M.E.J., van Heen, H.A., Mericskay, M., de Boer, H.A., and Nuijens, J.H. 1997 N-terminal stretch Arg2, Arg3, Arg4 and Arg5 of human lactoferrin is essential for binding to heparin, bacterial lipopolysaccharide, human lysozyme and DNA. Biochemistry J. 328:145-151.

Van Snick, J.L. and Masson, P.L. 1976 The binding of human lactoferrin to mouse peritoneal cells. J. Exp. Med. 144:1568-1580.

Van Snick, J.L., Masson, P.L. and Heremans, J.F. 1974 The involvement of lactoferrin in the hyposideremia of acute inflammation. J. Exp. Med. 140:1068-1084.

Varadhachary, A., Wolf, J.S., Petrak, K., O’Malley, B.W. Jr., Spadaro, M., Curcio, C., Forni, G. and Pericle, F. 2004 Oral lactoferrin inhibits growth of established tumors and potentiates conventional chemotherapy. Int. J. Cancer 111:398-403.

Wakabayashi, H., Kuwata, H., Yamauchi, K., Teraguchi, S. and Tamura, Y. 2004 No detectable transfer of dietary lactoferrin or its functional fragments to portal blood in healthy adult rats. Biosci. Biotechnol. Biochem. 68:853-860.

Wakabayashi, H., Yamauchi, K. and Takase, M. 2006. Lactoferrin research, technology and applications. Int. Dairy J. 16:1241-1251.

Wang, W.P., Iigo, M., Sato, J., Sekine, K., Adachi, I. and Tsuda H. 2000 Activation of intestinal mucosal immunity in tumor-bearing mice by lactoferrin. Jpn. J. Cancer Res. 91:1022-1027.

Ward, P.P., Paz, E. and Conneely, O.M. 2005 Multifunctional roles of lactoferrin: a critical overview. Cell. Mol. Life Sci. 62:2540-2548.

Ward, P.P., Uribe-Luna, S. and Conneely, O. 2002 Lactoferrin and host defence. Biochem. Cell Biol. 80:95-102.

Weinberg, E.D. 1984 Iron withholding: a defense against infection and neoplasia. Physiol. Rev. 64:65102.

Weinberg, E.D. 1992 Roles of iron in neoplasia. Promotion, prevention, and therapy. Biol. Trace Elem. Res. 34:123-140.

Weinberg, E.D. 1996 The role of iron in cancer. Eur. J. Cancer Prev. 5:19-36.

Weinberg, E.D. 2007. Antibiotic properties and applications of lactoferrin. Curr. Pharm. Design 13 (8): 801-811. 
Weinstein, R.E., Bond, B.H. and Silberberg, B.K. 1982 Tissue ferritin concentration in carcinoma of the breast. Cancer 50:2406-2409.

Wichmann, L., Vaalasti, A., Vaalasti, T. and Tuohimaa, P. 1989 Localization of lactoferrin in the male reproductive tract. Int. J. Androl. 12:179-186.

Xiao, Y., Monitto, C.L., Minhas, K.M. and Sidransky D. 2004 Lactoferrin down-regulates G1 cyclindependent kinases during growth arrest of head and neck cancer cells. Clin. Cancer Res. 10:86838686.

Yamauchi, K., Hiruma, M., Yamazaki, N., Wakabayashi, H., Kuwata, H., Teraguchi, S., Hayasawa, H., Suegara, N. and Yamguchi, H. 2000c Oral administration of bovine lactoferrin for treatment of tinea pedis. A placebo-controlled, double-blind study. Mycoses 43:197-202.

Yamauchi, K., Toida, T., Kawai, A., Nishimura, S., Teraguchi, S., and Hayasawa, H. 2000 b. Mutagenicity of bovine lactoferrin in reverse mutation test. J. Toxicol. Sci. 25: 63-66.

Yamauchi, K., Toida, T., Nishimura, S., Nagano, E., Kusuoka, O. Teraguchi, S., Hayasawa, H., Shimamura, S., and Tomita, M. 2000a. 13-week oral repeated administration toxicity study of bovine lactoferrin in rats. Food Chem. Toxicol. 38: 503-512.

Yamauchi, K., Tomita, M., Giehl, T.J. and Ellison, R.T. 1993 Antibacterial activity of lactoferrin and a pepsin-derived lactoferrin peptide fragment. Infect. Immun. 61:719-728.

Yamauchi, K., Wakabayashi, H., Shin, K. and Takase, M. 2006. Bovine lactoferrin: benefits and mechanism of action against infections. Biochem. Cell Biol. 84: 291-296.

Yi, M., Kaneko, S., Yu, D.Y. and Murakami, S. 1997 Hepatitis C virus envelope proteins bind lactoferrin. J. Virol. 71:5997-6002.

Yoo, Y.C., Watanabe, R., Koike, Y., Mitobe, M., Shimazaki, K., Watanabe, S. and Azuma, I. 1997b Apoptosis in human leukemic cells induced by lactoferricin, a bovine milk protein-derived peptide: involvement of reactive oxygen species. Biochem. Biophys. Res. Commun. 237:624-628.

Yoo, Y.C., Watanabe, S., Watanabe, R., Hata, K., Shimazaki, K. and Azuma I. 1997a Bovine lactoferrin and lactoferricin, a peptide derived from bovine lactoferrin, inhibit tumor metastasis in mice. Jpn. J. Cancer Res. 88:184-190.

Yoshida, S. and Ye, X. 1991. Isolation of lactoperoxidase and lactoferrins from bovine milk acid whey by carboxymethyl cation exchange chromatography. J. Dairy Sci. 74: 1439-1444.

Yu, R.H. and Schryvers, A.B. 1993 Regions located in both the N-lobe and C-lobe of human lactoferrin participate in the binding interactions with bacterial lactoferrin receptors. Microb. Pathog. 14:343353.

Zakharova, E.T., Shavloski, M.M., Bass, M.G., Gridasova, A.A., Pulina, M.O., De Filippis, V., Beltramini, M., Di Muro, P., Salvato, B., Fontana, A., Vasilyev, V.B. and Gaitskhoki, V.S. 2000 Interaction of lactoferrin with ceruloplasmin. Arch. Biochem. Biophys. 374:222-228.

Zimecki, M., Mazurier, J., Machnicki, M., Wieczorek, Z., Montreuil, J. and Spik, G. 1991 Immunostimulatory activity of lactotransferrin and maturation of CD4-CD8- murine thymocytes. Immunol. Lett. 30:119-123.

Zimecki, M., Mazurier, J., Spik, G. and Kapp, J.A. 1995 Human lactoferrin induces phenotypic and functional changes in murine splenic B cells. Immunology 86:122-127.

Zydney, A.L. 1998. Protein separations using membrane filtration: new opportunities for whey fractionation. Int. Dairy J. 8:243-250. 
Table 1 Occurrence of lactoferrin (hLF - human lactoferrin; bLF - bovine lactoferrin) in biological fluids

\begin{tabular}{|c|c|c|}
\hline & Biological fluid & Amounts reported \\
\hline \multirow{6}{*}{ 恄 } & Colostral breast milk & $>7$ \\
\hline & Mature breast milk & $>1-2$ \\
\hline & Tear fluid & $>2.2$ \\
\hline & Seminal plasma & $>0.4-1.9$ \\
\hline & Synovial fluid & $>0.01-0.08$ \\
\hline & Saliva & $>0.007-0.01$ \\
\hline \multirow{2}{*}{ 兵 } & Colostral whey & $>1.5$ \\
\hline & Milk & $>0.02-0.2$ \\
\hline
\end{tabular}

* Data adapted from Levay and Viljoen, 1995; Steijns and Van Hooijdonk, 2000; Babina et al., 2006; Shimazaki, 2000 
Table 2 Lactoferrin (hLF - human lactoferrin; bLF - bovine lactoferrin) physico-chemical properties

\begin{tabular}{lccl}
\hline & bLF & hLF & \multicolumn{1}{c}{ References } \\
\hline Amino acid residues & 689 & 690 & Pierce et al., 1991; Baker, 1994 \\
Molecular weight & $77 \pm 1.5$ & $76.8 \pm 1.6$ & $\begin{array}{l}\text { Querinjean et al., 1971; Spik et al., 1994; } \\
\text { Castellino et al., 1970 }\end{array}$ \\
Isoelectric point & $8.5-9.0$ & $8.4-9.0$ & $\begin{array}{l}\text { Spik et al., 1994; Lampreave et al., 1990; } \\
\text { Zakharova et al., 2000 }\end{array}$ \\
\hline
\end{tabular}


Table 3 Reported in vitro and in vivo physiological roles of lactoferrin

\begin{tabular}{|c|c|c|}
\hline Physiological role & Mechanism & References \\
\hline Iron absorption & $\begin{array}{l}\text { Increasing solubility and receptor } \\
\text { mediated uptake }\end{array}$ & $\begin{array}{l}\text { Kawakami et al., 1993; Mikogami et al., 1995; Levay } \\
\text { and Viljoen, 1995; Ward et al., } 2005\end{array}$ \\
\hline Antioxidant & $\begin{array}{l}\text { Iron scavenger } \\
\text { LF has the ability to bind to cell } \\
\text { membranes enhancing its ability } \\
\text { to prevent iron-mediated lipid } \\
\text { peroxidation }\end{array}$ & $\begin{array}{l}\text { Matsue et al., 1994; 1995; Konishi et al., 2006; } \\
\text { Larkins, } 2005\end{array}$ \\
\hline Antimicrobial & $\begin{array}{l}\text { Growth inhibition by iron } \\
\text { scavenging or membrane } \\
\text { disintegration } \\
\text { LF has a powerful iron-binding } \\
\text { capacity and shows a strong } \\
\text { interaction with other molecules } \\
\text { and cell surface }\end{array}$ & $\begin{array}{l}\text { Nemet and Simonovits, } 1985 \text {; Yamauchi et al., } 1993 \text {; } \\
\text { Qiu et al., } 1998 \text {; Weinberg, } 2007 \text {; Santagati et al., } \\
\text { 2005; Lönnerdal, } 2003 \text {; Lee et al., } 2005\end{array}$ \\
\hline Antiviral & $\begin{array}{l}\text { Prevention of virus attachment, } \\
\text { inhibition of virus replication, } \\
\text { blocking of cell-virus interactions }\end{array}$ & $\begin{array}{l}\text { Yi et al., } 1997 \text {; Siciliano et al., } 1999 \text {; Andersen et al., } \\
2001 \text {; Ikeda et al., } 2000 \text {; Giansanti et al., } 2002 \text {; } \\
\text { Longhi et al., 2006; Mistry et al., 2007; Ammendolia } \\
\text { et al., } 2007 \text {; Pan et al., } 2006\end{array}$ \\
\hline $\begin{array}{l}\text { Anti-inflammatory, } \\
\text { immune modulating }\end{array}$ & $\begin{array}{l}\text { LPS binding, stimulation of NK } \\
\text { cells, reduction of pro- } \\
\text { inflammatory cytokines, T-cell } \\
\text { maturation. } \\
\text { LF modulates the migration, } \\
\text { maturation and function of the } \\
\text { immune cells at the cellular level } \\
\text { and at the molecular level }\end{array}$ & $\begin{array}{l}\text { Zimecki et al., 1991, } 1995 \text {; Hangoc et al., } 1991 \text {; } \\
\text { Crouch et al., } 1992 \text {; Yamauchi et al., } 1993 \text {; Adamik } \\
\text { et al., } 1998 \text {; Baveye et al., } 1999 \text {; Dhennin-Duthille et } \\
\text { al., } 2000 \text {; Britigan et al., 2001; Fischer et al. 2006; } \\
\text { Berlutti et al. 2006; Senkovich et al., 2007; Legrand } \\
\text { et al., 2005; Kruzel et al., } 2006\end{array}$ \\
\hline Anti-cancer & $\begin{array}{l}\text { Regulation of NK cell activity, } \\
\text { modulation of expression of G1 } \\
\text { proteins, inhibition of } \\
\text { VEGF(165)-mediated } \\
\text { angiogenesis, enhancement of } \\
\text { apoptosis }\end{array}$ & $\begin{array}{l}\text { Bezault et al., } 1994 \text {; Sekine et al., } 1997 \text {; Yoo et al., } \\
\text { 1997b ; Damiens et al., 1998, } 1999 \text {; Norrby et al., } \\
2001 \text {; Mohan et al., 2006a; McKeown et al., 2006; } \\
\text { Kuhara et al., } 2006 \text {; Baumrucker et al. 2006; Kim et } \\
\text { al., 2006; Giuffre et al., } 2006 \text {; Kawakami et al., } 2006\end{array}$ \\
\hline
\end{tabular}


Table 4 Effectiveness of orally administered bLF in humans.

\begin{tabular}{|c|c|c|c|}
\hline Disease & Efficacy & $\begin{array}{l}\text { Administrated } \\
\text { agent and dose }\end{array}$ & References \\
\hline \multicolumn{4}{|l|}{ Bacterial flora: } \\
\hline $\begin{array}{l}\text { Faecal flora in low birth weight } \\
\text { infants }\end{array}$ & $\begin{array}{l}\text { Increase of Bifidobacterium, } \\
\text { decrease of Clostridium }\end{array}$ & $\begin{array}{l}\mathrm{bLF} ; 1 \mathrm{mg} / \mathrm{ml} \text { in } \\
\text { infant formula }\end{array}$ & $\begin{array}{l}\text { Wakabayashi et al., } \\
2006\end{array}$ \\
\hline Faecal flora in infants & Increase of Bifidobacterium & & $\begin{array}{l}\text { Roberts et al., 1992; } \\
\text { Logsdon et al., } 2006\end{array}$ \\
\hline \multicolumn{4}{|l|}{ Infection (digestive tract): } \\
\hline $\begin{array}{l}\text { Gastric infection with Helicobacter } \\
\text { pylori }\end{array}$ & $\begin{array}{l}\text { Increase of eradication by } \\
\text { triple therapy }\end{array}$ & bLF; 0.2g/body & Di Mario et al., 2003 \\
\hline \multicolumn{4}{|l|}{ Infection (other than digestive tract): } \\
\hline Neutropenic patients & $\begin{array}{l}\text { Decrease of incidence of } \\
\text { bacteremia and severity of } \\
\text { infection }\end{array}$ & bLF; 0.8 g/body & Trumpler et al., 1989 \\
\hline Chronic hepatitis C & $\begin{array}{l}\text { Decrease of ALT and HCV } \\
\text { RNA in serum }\end{array}$ & $\begin{array}{l}\text { bLF; } 1.8 \text { and } 3.6 \\
\text { g/body }\end{array}$ & $\begin{array}{l}\text { Tanaka et al., 1999; } \\
\text { Iwasa et al., 2002 ; } \\
\text { Yamauchi et al., 2000c ; } \\
\text { Konishi et al. 2006 ; } \\
\text { Katsuaki, } 2006\end{array}$ \\
\hline Influenza & $\begin{array}{l}\text { Attenuation of pneumonia } \\
\text { through the suppression of } \\
\text { infiltration of inflammatory } \\
\text { cells in the lung }\end{array}$ & $62.5 \mathrm{mg}$ per mouse & Shin et al., 2005 \\
\hline
\end{tabular}


Table 5 Effectiveness of orally administered LF-related compounds on cancers

\begin{tabular}{|c|c|c|c|c|}
\hline Cancer model & Efficacy & Animal & $\begin{array}{l}\text { Administrated } \\
\text { agent and dose }\end{array}$ & References \\
\hline $\begin{array}{l}\text { Carcinogen-induced tumour in } \\
\text { colon, lung, esophagus, } \\
\text { bladder, liver, tongue }\end{array}$ & $\begin{array}{l}\text { Inhibition of tumour } \\
\text { development }\end{array}$ & Rat & $\begin{array}{c}\text { bLF } \\
0.2 \text { and } 2 \% \text { in diet }\end{array}$ & $\begin{array}{l}\text { Sekine et al., 1997a, b; } \\
\text { Ushida et al., 1999; } \\
\text { Tanaka et al., 2000; } \\
\text { Masuda et al., 2000; } \\
\text { Fujita et al., 2002; Mohan } \\
\text { et al., 2006b }\end{array}$ \\
\hline $\begin{array}{l}\text { Spontaneously developed } \\
\text { intestinal polyposis }\end{array}$ & $\begin{array}{l}\text { Inhibition of polyp } \\
\text { development }\end{array}$ & $\begin{array}{l}\text { Apc }^{\text {Min }} \\
\text { mouse }\end{array}$ & $\begin{array}{c}\text { bLF } \\
2 \% \text { in diet }\end{array}$ & Ushida et al., 1998 \\
\hline Tumour cell injection & $\begin{array}{l}\text { Inhibition of lung } \\
\text { metastasis }\end{array}$ & Mouse & $\begin{array}{c}\mathrm{bLF} \\
0.3 \mathrm{~g} / \mathrm{kg}\end{array}$ & Iigo et al., 1999 \\
\hline Tumour cell injection & $\begin{array}{l}\text { Inhibition of tumour } \\
\text { development }\end{array}$ & Mouse & $\begin{array}{l}\mathrm{rhLF} \\
1 \mathrm{~g} / \mathrm{kg}\end{array}$ & Varadhachary et al., 2004 \\
\hline
\end{tabular}

